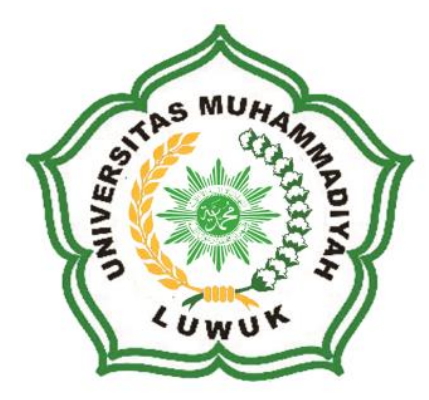

\title{
BUKU PANDUAN
}

\author{
KULIAH KERJA NYATA \\ PEMBELAJARAN PEMBERDAYAAN MASYARAKAT \\ (KKN-PPM) \\ UNIVERSITAS MUHAMMADIYAH LUWUK
}

TIM PENYUSUN :

Ir. SRI SUKARI AGUSTINA, M.Si. WINARTO RAMLAN, SP., MP. ERWIN NURSIN, S.Sos., M.Si.

LEMBAGA PENELITIAN, PENGEMBANGAN DAN PENGABDIAN KEPADA MASYARAKAT ( LP3M ) UNIVERSITAS MUHAMMADIYAH LUWUK 2019 


\section{KATA PENGANTAR}

Segala puji bagi Allah S.W.T karena atas rahmad dan hidayah-Nya sehingga penulisan buku panduan Kuliah Kerja Nyata-Pembelajatan Pemberdayaan Masyarakat (KKN-PPM) Universitas Muhammadiyah Luwuk dapat terselesaikan. Penerbitan buku panduan ini dijadikan acuan bagi Tim Pembina, Tim Monitoring, Dosen Pembimbing Lapangan (DPL), Panitia dan mahasiswa peserta Kuliah Kerja Nyata dalam pelaksanaan KKN-PPM di Universitas Muhammadiyah Luwuk.

Buku panduan ini disusun berdasarkan tujuan umum pelaksanaan KKN-PPM yakni mengembangkan kepribadian mahasiswa melalui kegiatan pengabdian kepada masyarakat. Garis besar buku panduan ini memuat pengertian KKN-PPM, misi, tujuan dan sasaran KKN-PPM, tata tertib, kewajiban, larangan dan sanksi, organisasi kerja, penyusunan kegiatan kerja dan administrasi KKN-PPM, serta evaluasi secara keseluruhan terhadap pelaksanaan KKN-PPM.

Sebagai buah karya pemikiran manusia, sebuah panduan tentu memiliki kelebihan dan kekurangan yang sering muncul dikarenakan adanya dinamika. Meskipun demikian sebuah buku panduan tetaplah menjadi sebuah acuan utama dalam pelaksanaan Kuliah Kerja Nyata. Revisi atas isi panduan selama pelaksanaan Kuliah Kerja NyataPembelajaran Pemberdayaan Masyarakat (KKN-PPM) berlangsung dengan maksud memperbaiki dan sinkronisasi 
pelaksanaan kegiatan Kuliah Kerja Nyata hanya dapat dilakukan melalui rapat Panitia Kuliah Kerja Nyata dan Dosen Pembimbing Lapangan. Oleh karena itu tidak dibenarkan siapapun juga merubah isi panduan secara sepihak. Akhir kata, semoga buku panduan ini dapat menjadi acuan selama pelaksanaan Kuliah Kerja Nyata Pembelajaran Pemberdayaan Masyarakat (KKN-PPM) Universitas Muhammadiyah Luwuk.

Luwuk, Juni 2019

LP3M UML 


\section{SAMBUTAN REKTOR}

Alhamdulillahirabbil'alamin, penyusunan Panduan Kuliah Kerja Nyata-Pembelajaran Pemberdayaan Masyarakat (KKN-PPM) Universitas Muhammadiyah Luwuk akhirnya dapat terselesaikan. Saya menyambut baik dan memberikan apresiasi yang tinggi terhadap Lembaga Penelitian, Pengembangan dan Pengabdian Kepada Masyarakat (LP3M) yang telah berupaya menyusun dan membuat panduan pelaksanaan kegiatan KKN-PPM ini.

Panduan Kuliah Kerja Nyata-Pembelajaran Pemberdayaan Masyarakat (KKN-PPM) Universitas Muhammadiyah Luwuk ini diharapkan menjadi pedoman bagi mahasiswa, Dosen Pembimbing Lapangan dan Tim Monitoring dalam pelaksanaan kegiatan di lapangan sehingga terbentuk keselarasan kerja antara mahasiswa, Dosen Pembimbing Lapangan dan Tim Monitoring serta LP3M sebagai pelaksana akademik bidang pengabdian masyarakat.

Akhir kata, saya selaku Rektor Universitas Muhammadiyah Luwuk mengajak kita semua segenap civitas akademika, dengan niat tulus demi kemajuan Universitas Muhammadiyah Luwuk, mari kita selalu memohon dengan Ridha Allah SWT bersama-sama melaksanakan kegiatan Kuliah Kerja Nyata-Pembelajaran Pemberdayaan Masyarakat (KKN-PPM) sebagai wujud pengabdian Universitas 
Muhammadiyah Luwuk untuk turut serta memberdayakan masyarakat dalam pembangunan bangsa dan negara.

Luwuk, Juni 2019

Rektor

Dr. Farid Haluti, S.Ag., M.Pd. 


\section{DAFTAR ISI}

HALAMAN SAMPUL......................................... i

KATA PENGANTAR .............................................. ii

SAMBUTAN REKTOR ....................................... iv

DAFTAR ISI .................................................... vi

DAFTAR LAMPIRAN ......................................... viii

BAB I. PENDAHULUAN

1.1. Kuliah Kerja Nyata-Pembelajaran

Pemberdayaan Masyarakat (KKN-PPM) ......

1.2. Misi, Tujuan, dan Sasaran

BAB II. TATA TERTIB KKN-PPM

2.1.Pra Pembekalan, Pembekalan dan

Seminar

2.2. Kewajiban Selama di Lokasi KKN-PPM

2.3. Ketentuan KKN-PPM

2.4. Sanksi

2.5. Surat Peringatan (SP) dan Rekomendasi ....

BAB III. DESKRIPSI ORGANISASI KKN-PPM

3.1. Rektor .

3.2. Wakil Rektor

3.3. Tim Monitoring

3.4. Panitia KKN

3.5. Dosen Pembimbing Lapangan (DPL)

3.6. Koordinator Kecamatan dan Koordinator

Desa.

BAB IV. PENYUSUNAN KEGIATAN KERJA DAN

ADMINISTRASI KKN-PPM

4.1. Ketentuan Bidang Program/Kegiatan KKN.

4.2. Teknik Penyusunan ...

4.3. Teknik Penulisan Kertas Matriks Rencana

dan Pelaksanaan Kegiatan .....................

4.4. Administrasi KKN-PPM 
BAB V. ARTIKEL ILMIAH MAHASISWA

BAB VI. EVALUASI DAN PENILAIAN KKN

6.1. Pembekalan

6.2. Penilaian Kegiatan Lapangan KKN-PPM ....

6.3. Nilai Akhir Peserta KKN-PPM

6.4. Nilai Tunda

LAMPIRAN 


\section{DAFTAR LAMPIRAN}

Nomor

Teks

Halaman

1. Laporan Kelompok

2. Artikel Ilmiah Mahasiswa 


\section{BAB I}

\section{PENDAHULUAN}

\subsection{Kuliah Kerja Nyata-Pembelajaran Pemberdayaan Masyarakat (KKN-PPM)}

Kegiatan Kuliah Kerja Nyata (KKN) merupakan kegiatan lapangan bagi mahasiswa yangmenempuh bagian akhir dari program pendidikan S-1. Program ini bersifat wajib bagi semua mahasiswa, karena universitas mempercayai bahwa program ini mampu mendorong empati mahasiswa, dan dapat memberikan sumbangan bagi penyelesaian persoalan yang ada di masyarakat. Dengan belajar bersama-sama masyarakat, akan banyak hal baru yang ditemui mahasiswa. Masyarakat akan belajar dari mahasiswa dan sebaliknya mahasiswa akan banyak memperoleh pengetahuan dari masyarakat. Interaksi seperti inilah yang diharapkan akan muncul dan menjadikan program ini sebagai program yang menyenangkan dan mempunyai manfaat yang signifikan bagi mahasiswa di universitas, masyarakat dan stakeholders atau mitra. Pengabdian masyarakat berbasis riset mendapatkan bentuknya yang nyata dalam kegiatan Kuliah Kerja Nyata. Program ini juga merupakan wujud nyata peran mitra (industri/Pemda) dalam membantu menyelesaikan persoalanpersoalan masyarakat.

Kegiatan KKN menjadi bentuk nyata kontribusi universitas bagi masyarakat, industri, pemerintah daerah dan kelompok masyarakat yang ingin mandiri secara ekonomi maupun sosial. Program KKN mensyaratkan Dosen Pembimbing Lapangan (DPL) dan mahasiswa berperan aktif dalam mengetahui permasalahan yang ada, bahkan sebelum mereka terjun di tengah-tengah masyarakat. Konsep "working with community" telah menggantikan konsep "working for the community". Untuk menjaga citra dan mutu kegiatan KKN tersebut, sudah selayaknya kegiatan KKN tersebut lebih kontekstual dengan mengubah paradigma pembangunan (development) menjadi paradigma pemberdayaan (empowerment). Atas dasar hal tersebut di atas, revitalisasi Kuliah Kerja Nyata menjadi Kuliah Kerja Nyata-Pembelajaran Pemberdayaan Masyarakat (KKN-PPM) di PerguruanTinggi Universitas Muhammadiyah Luwuk sangatlah penting untuk dilakukan.

Beberapa strategi dapat ditempuh dalam menerapkan KKN di Perguruan Tinggi agar dalam pelaksanaannya dapat menjadi tools solusi penanganan masalah pembangunan di Indonesia, yaitu dengan konsep pemberdayaan berbasis masyarakat, di antaranya adalah mengembangkan tema-tema KKN-PPM yang bermitra dengan pemerintah dan dunia usaha, mengembangkan tema-tema KKN-PPM dengan konsep co-creation, co-financing dan co-benefit. KKN-PPM sebagai pembaharu kegiatan kemahasiswaan yang mendorong kepemimpinan berkualitas perlu senantiasa mengembangkan kemitraan dengan industri/Pemda/Perguruan Tinggi lainnya.

\subsection{Misi,Tujuan, dan Sasaran}

\subsubsection{Misi}

a. Mewujudkan peran Universitas Muhammadiyah Luwuk kepada masyarakat.

b. Memfasilitasi, memotivasi dan mendinamiskan pemberdayaan masyarakat untuk tumbuh secara mandiri.

c. Mengembangkan pendidikan, ilmu pengetahuan dan keterampilan kepada warga masyarakat dan aparat pemerintah Desa/Kelurahan di lokasi KKN-PPM.

d. Menemukan informasi tentang permasalahan yang dihadapi oleh masyarakat dan aparat di lokasi KKNPPM.

e. Melahirkan solusi jangka pendek dalam bentuk kegiatan KKN-PPM. 


\subsubsection{Tujuan}

a. Mengubah pelaksanaan program KKN-PPM dari paradigma pembangunan (development) menjadi paradigma pemberdayaan (empowerment)

b. Terwujudnya kemitraan antara Universitas Muhammadiyah Luwuk dengan masyarakat.

c. Mendidik mahasiswa sebagai perencana, motivator, fasilitator dan penggerak pembangunan.

d. Membantu masyarakat dalam memberdayakan diri.

\subsubsection{Sasaran}

a. Terciptanya kepercayaan masyarakat terhadap Universitas Muhammadiyah Luwuk.

b. Terbentuk mahasiswa yang memiliki sikap dan kepribadian yang unggul penuh nilai-nilai berkehidupan berbangsa dan bernegara.

c. Terbentuknya masyarakat yang mampu memberdayakan diri. 


\section{BAB II}

\section{TATA TERTIB KKN-PPM}

\subsection{Pra Pembekalan, Pembekalan dan Seminar}

1. Peserta Kuliah Kerja Nyata wajib mengikuti pra pembekalan, pembekalan dan seminar

2. Selama mengikuti pembekalan peserta wajib mengenakan pakaian baju putih dan celana/rok hitam, sedangkan selama mengikuti seminar KKN wajib menggunakan jaket KKN. Khusus wanita yang muslim diwajibkan menggunakan jilbab selama kegiatan pembekalan dan seminar.

3. Setiap peserta KKN minimal memiliki $75 \%$ kehadiran dan membuat resume lengkap sebagai syarat untuk kelulusan mengikuti KKN.

4. Tidak boleh merokok di dalam ruangan selama kegiatan pembekalan atau seminar akhir.

\subsection{Kewajiban Selama di Lokasi KKN-PPM}

1. Menjunjung tinggi nilai-nilai Al Islam dan Kemuhammadiyahan.

2. Menjunjung tinggi nilai-nilai almamater.

3. Menjunjung tinggi dan menghormati nilai-nilai dan adat istiadat lokasi penempatan.

4. Menghormati hukum dan peraturan yang berlaku.

5. Mematuhi dan melaksanakan ketentuan KKN baik yang disampaikan oleh Ketua Panitia maupun DPL.

6. Setiap peserta wajib berada di lokasi Kuliah Kerja Nyata sesuai penetapan lokasi oleh panitia KKN.

7. Selama berada di lokasi Kuliah Kerja Nyata, peserta wajib berpakaian sopan, menggunakan salah satu atribut $\mathrm{KKN}$ atau keseluruhan sebagai tanda pengenal/ identitas.

8. Khusus wanita yang muslim diwajibkan menggunakan jilbab selama kegiatan KKN sebagai penciri AlK.

9. Peserta KKN wajib mengisi dan melengkapi administrasi KKN.

10.Peserta KKN wajib mematuhi dan mengikuti system Akademik KKN.

11.Peserta KKN tidak dibenarkan membuat kop surat dan stempel baik atas nama kelompok maupun panitia Kuliah Kerja Nyata, sebab peserta KKN berada atau bagian dari pemerintah Desa/Kelurahan semenjak penyerahan hingga saat penarikan.

12.Peserta KKN selalu berkoordinasi dengan Pemerintah di lokasi penempatan.

\subsection{Ketentuan KKN-PPM}

\section{A. Pelanggaran Ringan}

1. Meninggalkan lokasi lebih dari 3 hari tanpa izin baik berturut-turut atau tidak.

2. Tidak mengisi buku Aktivitas Harian individu 3 hari berturut-turut.

3. Kertas Kegiatan kerja kelompok belum dibuat lebih dari 3 hari di lokasi.

4. Tidak mengikuti dan melaksanakan instruksi DPL dan Ketua Panitia.

5. Tidak mengikuti aturan yang telah ditetapkan oleh panitia.

\section{B. Pelanggaran Sedang}

1. Mahasiswa yang telah mendapat peringatan pertama tetapi tidak ada perbaikan

2. Meninggalkan lokasi lebih dari 10 hari tanpa izin baik berturut-turut atau tidak.

3. Meminta sumbangan kepada perseorangan di lokasi penempatan atau instansi pemerintah untuk kegiatan Kuliah Kerja Nyata.

4. Perpindahan lokasi sepihak oleh peserta tanpa surat resmi dari Panitia.

5. Tidak mengindahkan peringatan/instruksi DPL dan Ketua Panitia KKN. 
6. Tidak mengisi buku Aktivitas Harian individu sampai dengan 14 hari berturut-turut.

7. Tidak memperbaiki buku Aktivitas Harian individu sampai dengan 14 hari berturut-turut.

8. Tidak mendukung dan kurang berpartisipasi aktif dalam membantu teman dan kegiatan kelompok.

9. Tidak menjaga sikap baik terhadap warga, aparat pemerintah maupun terhadap teman satu kelompok.

\section{Pelanggaran Berat}

1. Mahasiswa yang telah mendapat peringatan, kedua atau ketiga tetapi tidak ada perbaikan.

2. Tidak berada dilokasi KKN sesuai penetapan lokasi oleh Panitia KKN.

3. Meninggalkan lokasi 15 hari baik secara berturut-turut atau pun tidak berturut-turut.

4. Melanggar nilai-nilai dan adat istiadat lokasi penempatan.

5. Melanggar nilai-nilai Al Islam dan Kemuhammadiyahan;

6. Mencemarkan nama baik almamater.

7. Tidak mengikuti dan melaksanakan instruksi DPL berulang-ulang.

8. Melakukan kegiatan yang terindikasi atau bersifat politik dan kepartaian.

9. Melakukan tindakan bersifat pidana.

10.Melanggar peraturan Desa/Kelurahan dan peraturan pemerintah yang lebih tinggi.

11.Mengorganisasi dan atau menyelenggarakan kegiatan yang dapat mengganggu ketertiban umum.

12.Melakukan tindakan yang dapat mengganggu, membahayakan keselamatan kelompok atau anggota kelompok.

13.Melakukan tindakan/pelanggaran KKN dan berdampak buruk setelah selesainya kegiatan KKN.

14.Sengaja atau tidak menyebabkan orang diluar kelompok melakukan terror atau menyerang anggota kelompok

15.Menyebabkan keributan dan perpecahan dalam kelompok

\subsection{Sanksi}

\section{A. Pembekalan}

Peserta KKN yang sama sekali tidak mengikuti kegiatan pembekalan tanpa alasan yang jelas dan atau kehadirannya kurang dari $75 \%$, maka digugurkan oleh Ketua Panitia sebagai perserta Kuliah Kerja Nyata dan menunggu KKN berikutnya.

\section{B. Kegiatan Lapangan Kuliah Kerja Nyata}

1. Sanksi diberikan kepada mahasiswa yang telah mendapat peringatan tertulis tingkat 3 (SP-3) tetapi tidak ada perubahan.

2. Sanksi diberikan karena terbukti melakukan pelanggaran berat.

3. Sanksi diberikan melalui Sidang Disiplin KKN yang dipimpin Ketua LP3M dan dihadiri oleh DPL, Ketua Panitia dan Pengurus LP3M.

4. Bentuk sanksi mulai dari pemindahan peserta, penundaan kepesertaan $\mathrm{KKN}$, pengurangan nilai KKN, penambahan beban KKN, penarikan dari lokasi KKN, -pengguguran kepesertaan KKN.

\section{Pasca Kegiatan Lapangan}

Mahasiswa yang terbukti melakukan pelanggaran KKN dan berdampak buruk setelah selesainya kegiatan KKN, maka akan tetap dikenakan sanksi sesuai jenis dan tingkat pelanggaran dalam pelaksanaan $\mathrm{KKN}$. 


\subsection{Surat Peringatan (SP) dan Rekomendasi}

Surat peringatan (SP) adalah surat teguran yang dikeluarkan oleh Ketua Panitia KKN dan ditujukan kepada peserta KKN baik secara kelompok maupun secara perorangan. Surat teguran dilakukan secara bertingkat atau langsung kepada tingkatan tertentu tergantung jenis pelanggaran yang dilakukan. Bentuk surat teguran terdiri atas :

a. Surat Peringatan tingkat Pertama disingkat SP-1. Diberikan untuk teguran pertama terhadap pelanggaran ringan. Penerbitan melalui mekanisme rapat dengan DPL atau atas permintaan DPL tanpa rapat. Penerbitan didasarkan pada temuan DPL, temuan Ketua Panitia dan temuan Tim Monitoring.

b. Surat Peringatan tingkat Kedua disingkat SP-2. Diberikan untuk teguran kedua terhadap pelanggaran ringan. Penerbitan melalui mekanisme rapat dengan DPL atau atas permintaan DPL tanpa rapat. Penerbitan didasarkan pada temuan DPL, temuan Ketua Panitia dan temuan Tim Monitoring.

c. Surat Peringatan tingkat Ketiga disingkat SP-3. Diberikan untuk teguran ketiga terhadap pelanggaran ringan dan pelanggaran sedang. Penerbitan melalui mekanisme rapat dengan DPL atau permintaan DPL secara langsung. Penerbitan didasarkan pada temuan DPL, temuan Ketua Panitia dan temuan Tim Monitoring.

d. Untuk pelanggaran berat, sanksi diterbitkan melalui Sidang Disiplin Ketua Panitia bersama LP3M. Penerbitan didasarkan pada temuan DPL, temuan Ketua Panitia dan temuan Tim Monitoring. 


\section{BAB III \\ DESKRIPSI ORGANISASI KKN-PPM}

\subsection{Rektor}

Adalah pimpinan tertinggi dalam pengelolaan Universitas Muhammadiyah Luwuk.

\subsection{Wakil Rektor}

Adalah atasan langsung LP3M dan bertindak sebagai penasehat serta pengarah dalam kegiatan KKN.

\subsection{Tim Monitoring}

a. Tim monitoring adalah Ketua LP3M sebagai koordinator dan beranggotakan pengurus Bidang-bidang LP3M dan atau Dosen yang ditunjuk dalam Surat Keputusan kepanitiaan KKN.

b. Tim monitoring berwenang untuk mengamati, bertanya, mencatat dan mengevaluasi kinerja Panita KKN, DPL dan Mahasiswa KKN dalam pelaksanaan KKN yang sedang berjalan.

c. Koordinator Tim Monitoring dapat mengganti Ketua Panitia, jajaran panitia, DPL berdasarkan Instruksi Rektor, temuan Tim Monitoring atau permintaan Ketua Panitia, melalui mekanisme rapat LP3M.

\subsection{Panitia KKN-PPM}

a. Adalah Tim yang dibentuk oleh LP3M UML yang bertugas sebagai pelaksana harian kegiatan pembekalan, kegiatan lapangan dan penutupan Kuliah Kerja Nyata UML, yang terdiri dari Ketua, sekretaris dan bendahara serta dibantu oleh beberapa orang staf.

b. Ketua Panitia bertugas memimpin, mengarahkan, memonitoring dan mengevaluasi pelaksanaan kegiatan KKN mulai dari persiapan, pembekalan, pelaksanaan hingga selesainya seluruh rangkaian kegiatan KKN.

c. Sekretaris Panitia bertugas membantu Ketua Panitia dalam bidang administrasi dan kesekretariatan serta dapat mewakili Ketua bila Ketua Panitia Berhalangan tidak tetap dalam bidang administrasi.

d. Bendahara Panitia bertugas membantu Ketua Panitia dalam bidang perlengkapan dan Keuangan serta dapat mewakili Ketua bila Ketua Panitia berhalangan tidak tetap dalam bidang perlengkapan dan keuangan.

c. Dalam menyelenggarakan kegiatan Kuliah Kerja Nyata, panitia KKN dibantu oleh Dosen Pembimbing Lapangan (DPL) yang ditunjuk oleh LP3M.

e. Ketua Panitia berwenang menetapkan lokasi penempatan mahasiswa peserta KKN.

f. Ketua Panitia dalam keadaan genting atau mendesak, tanpa melalui rapat evaluasi bersama DPL, dapat memindahkan lokasi mahasiswa peserta, menarik mahasiswa peserta dengan diketahui oleh Ketua LP3M.

g. Ketua Panitia berwenang mengamati, bertanya dan mencatat temuan dilapangan dan membawanya dalam rapat evaluasi bersama DPL dengan dihadiri oleh Tim Monitoring.

h. Ketua Panitia memiliki kewenangan mengeluarkan surat peringatan, pemberian sanksi dan menggugurkan peserta KKN melalui rapat Evaluasi bersama DPL.

i. Ketua Panitia dapat mengambil tindakan dan kebijakan yang diperlukan dalam kegiatan KKN dengan diketahui oleh LP3M.

k. Ketua Panitia dapat menegur secara tertulis kepada DPL yang melanggar atau mengganggu atau menghambat jalannya KKN atau tidak dapat bekerja sama. Teguran ditembuskan ke LP3M.

I. Ketua panitia dapat meminta atau mengusulkan penggantian DPL kepada LP3M.

m. Ketua Panitia KKN mendampingi Rektor dan Wakil Rektor pada saat kunjungan ke lokasi KKN. 
k. Ketua Panitia KKN membuat laporan pelaksanaan kegiatan KKN kepada LP3M setelah penetapan nilai akhir.

\subsection{Dosen Pembimbing Lapangan (DPL)}

1. Dosen Pembimbing Lapangan selanjutnya disingkat DPL, direkrut dan ditetapkan oleh LP3M UML,

2. DPL berkewajiban :

a. Bekerja dibawah komando Ketua Panitia dalam membimbing dan mengevaluasi peserta KKN UML mulai penempatan hingga penutupan kegiatan KKN, sesuai Surat Keputusan penetapan lokasi oleh Panitia KKN.

b. Mengikuti ketentuan panitia dan bekerja sama dalam mensukseskan pelaksanaan KKN.

c. Mengantar, membimbing, mendampingi dalam kegiatan seminar dan penarikan mahasiswa KKN bimbingannya saat penutupan kegiatan lapangan.

d. Berkoordinasi dan berkomunikasi serta bekerja sama dengan DPL lain di wilayah kerja yang sama dalam pembimbingan dan evaluasi.

e. Menyetorkan nilai evaluasi terhadap mahasiswa KKN yang dibimbingnya kepada Ketua Panitia.

3. Larangan bagi DPL:

a. Melakukan pemindahan sepihak peserta KKN tanpa persetujuan Ketua Panitia secara tertulis dan ditembuskan kepada Kepala Desa/Lurah,

b. Meminta upeti atau bentuk lainnya yang dapat membebani mahasiswa peserta KKN.

c. Menarik pembayaran atau uang dari mahasiswa diluar ketentuan panitia.

d. Melakukan pembimbingan dengan cara mengumpulkan semua mahasiswa bimbingannya pada satu tempat dan bukan dengan cara mengunjungi posko peserta KKN.

4. DPL dapat diberhentikan oleh LP3M saat KKN berlangsung berdasarkan permintaan Ketua Panitia KKN atau instruksi Rektor atau temuan langsung hal-hal yang dianggap melanggar atau mengganggu atau menghambat jalannya KKN atau tidak dapat bekerja sama.

5. Kewenangan DPL

a. Dalam keadaan tertentu dengan pertimbangan keselamatan, DPL dapat memindahkan peserta bimbingannya dalam wilayah bimbingannya atau mengembalikan peserta ke Ketua Panitia, dan melaporkan ke Ketua Panitia untuk resminya.

b. Meminta atau merekomendasikan pemindahkan lokasi peserta KKN karena keadaan tertentu dan atau sebab tertentu yang dipandang mendesak dan penting kepada Ketua Panitia.

c. DPL dapat menolak keberadaan peserta KKN tanpa persetujuan Ketua Panitia tembusan Kepala Desa/Lurah.

d. DPL bisa meminta surat peringatan, pemberian sanksi atau pengguguran peserta KKN bimbingannta kepada Ketua Panitia terhadap mahasiswa yang melanggar ketentuan.

e. Melakukan evaluasi dan penilaian KKN terhadap mahasiwa bimbingannya.

\subsection{Koordinator Kecamatan dan Koordinator Desa}

\subsubsection{Koordinator Kecamatan Mahasiswa KKN}

a. Koordinator kecamatan selanjutnya disebut Korcam dipilih oleh anggota kelompok berdasarkan kemampuan dan keterampilan, dan harus memiliki daya mobilitas yang tinggi serta dapat diberhentikan oleh anggota jika melanggar ketentuan KKN berdasarkan persetujuan Tim DPL.

b. Melakukan fungsi koordinasi peserta KKN dengan pemerintah, tokoh masyarakat dan stakeholder di wilayahnya. 
c. Melayani, mendorong dan memotivasi setiap peserta Kuliah Kerja Nyata di wilayah kerjanya.

d. Korcam tidak dibenarkan mengintervensi, merubah program kerja desa atau merubah ketentuan yang telah ditetapkan DPL.

e. Korcam tidak dibenarkan bertindak secara otoriter, tetapi bertindak berdasarkan musyawarah dan mufakat.

f. Mengkomunikasikan semua kegiatan yang ada di wilayah kerjanya kepada pemerintah, tokoh masyarakat dan sebaliknya.

g. Menguasai permasalahan-permasalahan yang timbul dan memberi alternatif pemecahan masalah atau mengkoordinasikan dengan Tim DPL diwilayah kerjanya.

h. Wajib mendampingi setiap kunjungan Pembina KKN , Monitoring LP3M dan Ketua Panitia KKN.

\subsubsection{Koordinator Desa}

a. Kordes dipilih oleh anggota kelompok berdasarkan kemampuan dan keterampilan serta dapat diberhentikan oleh anggota jika melanggar ketentuan KKN berdasarkan persetujuan DPL.

b. Bertanggungjawab terhadap kegiatankelompok di desa yang bersangkutan

c. Mengkoordinasikan anggota kelompoknya dalam melaksanakan observasi, perencanaankegiatan kerja dan dalam pelaksanaan kegiatan kerja.

d. Mewakili kelompok dalam koordinasi dengan pemerintah desa, tokoh masyarakat dan kelompok lain.

e. Melayani, menjaga dinamika, kekompakkan, keutuhan dan kesejahteraan serta keselamatan anggotanya dalam melaksanakan tugas Kuliah Kerja Nyata.

f. Selalu berkoordinasi dengan Korcam dan DPL. 


\section{BAB IV}

\section{PENYUSUNAN KEGIATAN KERJA DAN ADMINISTRASI KKN-PPM}

\subsection{Ketentuan Bidang Program/ Kegiatan KKN}

Setiap mahasiswa peseta KKN memiliki Jam Kerja Efektif Mahasiswa (JKEM) yang terdiri atas JKEM Kehadiran minimal 12.960 menit dan JEKM Program kerja 16.280 menit selama pelaksanaan lapangan, meliputi bidang Program Kegiatan KKN:

a. Kegiatan Bidang IImu, yaitu kegiatan KKN yang berkaitan dengan kompetensi lulusan atau keahlian berkarya sesuai dengan bidang ilmu/ Program Studi. Setiap peserta KKN harus memiliki minimal 1 kegiatan. Beban kerja kegiatan ini minimal setara 600 menit per orang.

b. Kegiatan Bersama bidang Keagamaan yatu kegiatan KKN yang berkaitan dengan kegiatan yang bersifat menghidupkan kegiatan ibadah, pembinaan mental dan akhlaq, pembimbingan dan peringatan hari-hari besar keagamaan dan jika memungkinkan perbaikan/pengadaan sarana tempat ibadah atau Taman Pengajian. Dibidang ini peserta KKN secara bersama-sama harus melaksanakan program/kegiatan KKN minimal 3 jenis/macam kegiatan atau setara 1800 menit.

c. Kegiatan Bersama Bidang Seni dan Olahraga, adalah kegiatan yang bersifat pembinaan seni dan olah raga, kegiatan prestasi seni dan olah raga. Dibidang ini peserta KKN secara bersama-sama harus melaksanakan program/kegiatan KKN minimal 1 jenis/macam kegiatan seni minimal 1800 menit dan 1 jenis kegiatan olahraga minimal 1800 menit.

d. Kegiatan Bersama tematik dan Non Tematik. Kegiatan tematik adalah kegiatan yang mengangkat satu tema untuk jadi unggulan atau penciri lokasi penempatan KKN dengan beban kerja minimal 1800 menit. Sedangkan Kegiatan non tematik adalah kegiatan lain berdasarkan permintaan atau kebutuhan masyarakat, permintaan Perangkat Desa, Pemerintah Kecamatan atau instansi setingkat Kecamatan, Instansi Kabupaten, dengan beban kerja minimal setara 3000 menit.

e. Kegiatan wajib universitas adalah kegiatan yang wajib ada dalam setiap kelompok KKN, terdiri atas kegiatan sosialisasi Universitas Muhammadiyah Luwuk dengan beban kerja minimal setara 480 menit dan Pameran KKN dengan beban kerja minimal setara 960 menit.

f. Penulisan artikel pengabdian kepada masyarakat.

\subsection{Teknik Penyusunan}

\subsubsection{Persiapan Lapangan}

Kegiatan pendekatan sosial terhadap masyarakat, tokoh/pemuka masyarakat, aparat dan pemerintah guna pendalaman hasil survey dan perumusan program/kegiatan KKN. Persiapan ini dilakukan dengan cara mengunjungi rumah dan tempat kerja warga, sosialisasi/ perkenalan di balai desa atau tempat lainnya, serta berinteraksi pada awal kedatangan/penempatan dengan masyarakat lokasi KKN.

4.2.3. Perencanaan Program dan kegiatan

1. Lakukan pembagian tugas dan fungsi organ KKN dipimpin oleh Kordes.

2. Buat form/ miniatur kertas kegiatan kerja.

3. Berdasarkan pendalaman hasil survey, buat rumusan kegiatan dengan mempertimbangkan waktu kerja dalam menit.

4. Presentasikan dalam rapat desa dalam rangka kegiatan KKN.

5. Perbaiki hasil rapat, dan ditandasyahkan oleh DPL serta diketahui oleh Kepala Desa. 
6. Pindahkan dengan segera kedalam kertas program dan kegiatan menggunakan kertas milimeterblok sebagai Pedoman Rencana Tindak Resmi Kegiatan KKN. Ukuran kertas yang digunakan adalah lebar minimal $150 \mathrm{~cm}$ dan tinggi menyesuaikan.

7. Tempelkan/ gantung kertas milimeterblok paling lambat 3 hari setelah pemaparan dan ditandasyahkan oleh DPL serta diketahui oleh Kepala Desa atau Lurah.

4.2.4. Teknik menghitung estimasi/ prakiraan waktu kerja

Sesuai standar waktu internasional. 1 jam $=60$ menit maka:

Contoh 1:

"Penyuluhan Bahaya Stunting bagi Balita". Untuk melaksanakan kegiatan ini minimal terdiri atas tahap perencanaan, tahap persiapan dan tahap pelaksanaan. Tahap perencanaan membutuhkan waktu 120 menit, tahap persiapan membutuhkan waktu 120 menit, dan tahap pelaksanaan membutuhkan waktu 120 menit, sehingga total waktu yang dibutuhkan adalah 260 menit.

Contoh 2:

"Pendataan Administrasi bukti Kepemilikan Tanah". Kegiatan ini terbagi atas $\mathbf{3}$ tahapan, yakni perencanaan, persiapan, pelaksanaan.

\section{Kegiatan perencanaan :}

- Rapat 2 kali ( penggunaan waktu satu kali rapat 120 menit)

$=240$ menit.

\section{Kegiatan Persiapan}

- membuat format isian data kepemilikan tanah 120 menit $\times 3$ hari

$=360$ menit

\section{Kegiatan Pelaksanaan}

- pengumpulan data 120 menit / hari $\times 4$ hari

$=480$ menit

- tabulasi data 120 menit / hari $\times 3$ hari

$=360$ menit

Jadi total waktu kegiatan Pendataan administrasi kepemilikan tanah $=1.440$ menit

\subsection{Teknik Penulisan Kertas Matriks Rencana dan Pelaksanaan Kegiatan}

1. Buatlah kolom dan baris sesuai dengan format 1 tentang Matriks Rencana dan Pelaksanaan Kegiatan.

2. Tulis dan lengkapi kepala/judul Kegiatan Kerja sesuai dengan lokasi penempatan.

3. Kegiatan yang telah disepakati dalam kegiatan pemaparan, tulis dalam kolom program (kolom 1). Dalam kolom program terdiri atas judul Program contoh:" Bidang Keilmuan". Dibawah judul Program ditulis nama Kegiatan Kerja sesuai dengan jumlah anggota KKN.

4. Isi kolom ke-2 dengan nama bulan pelaksanaan KKN. Nama bulan disesuaikan dengan lamanya waktu pelaksanaan KKN di lapangan. Dibawah nama bulan dibuat kolom tanggal sesuai dengan waktu kerja dalam bulan berjalan. Selanjutnya dibawah angka tanggal tidak perlu digaris-garis, cukup meluruskan/sejajarkan dengan kolom angka tanggal. Setiap tanggal rencana kerja diberi/diarsir warna merah, sedangkan pelaksanaan berwarna biru. Arsiran perencanaan pada bagian atas, sedangkan arsiran pelaksanaan pada bagian bawah.

5. Isi kolom ke-3 pelaksa kegiatan. Untuk mahasiswa cukup indeks alphabet sedangkan untuk masyarakat atau nama instansi tetap ditulis.

6. Dibawah matriks diberi keterangan rencana kerja dengan warna merah, pelaksanaan dengan warna biru dan indeks disertai nama mahasiswa KKN lengkap dengan nomor pokok mahasiswa (NPM).

7. Konsultasikan dengan DPL jika belum paham atau terjadi perbedaan pendapat dalam penulisan.

8. Segera tandasyahkan kepada DPL dan diketahui oleh Kepala Pemerintahan lokasi penempatan. Keterlambatan dapat menyebabkan terbitnya surat Peringatan. 


\subsection{Administrasi KKN-PPM}

\subsubsection{Buku Aktifitas Harian}

Buku ini terdiri atas beberapa bagian yakni Catatan Aktifitas Harian, Gerakan Silaturrahim, Gerakan sholat berjama'ah, Kartu Tugas di luar Lokasi/lzin Meninggalkan Lokasi, Rekapan Aktifitas Mahasiswa KKN.

\section{A. Catatan Aktifitas Harian}

Catatan aktifitas harian adalah pencatatan aktifitas harian oleh setiap individu peserta KKN selama melaksanakan KKN. Catatan ini diisi setiap hari. Format 2.

\section{B. Gerakan Silaturrahim}

Saat melakukan pendekatan sosial diawal kedatangan peserta wajib melakukan silaturahim kepada masyarakat, tokoh masyarakat dan agama, instansi terkait. Hal ini dibuktikan dengan buku gerakan silaturrahim. Form ditandatangani/paraf oleh tempat yang dikunjungi. Format 3.

\section{Gerakan sholat berjama'ah}

Mahasiswa KKN Perguruan Tinggi Muhammadiyah diwajibkan untuk menghidupkan suasana Al Islam dan Kemuhammadiyahan melalui gerakan sholat berjama'ah selama mengikuti kegiatan KKN baik mahasiswa laki-laki maupun perempuan. Mahasiswa laki-laki diwajibkan di masjid, sedangkan perempuan tidak wajib di masjid. Hal ini dibuktikan dengan buku gerakan sholat berjamaah. Setiap halaman dimintakan tandatangan takmir masjid/ imam. Format 4.

\section{Izin Meninggalkan Lokasi}

Terdapat 2 Format yakni Format 5A untuk meninggalkan lokasi dalam rangka tugas KKN dan Format 5B untuk meninggalkan lokasi bukan dalam rangka tugas $\mathrm{KKN}$. Untuk $5 \mathrm{~A}$ cukup diisi dan paraf oleh Kordes atau sesuai petunjuk DPL. Untuk 5B harus diparaf oleh aparat.

\section{E. Rekapitulasi Aktifitas Harian Individu}

Form ini diisi saat minggu terakhir di lokasi KKN dan dijadikan dasar dalam menyusun Laporan Kelompok Desa/ Kelurahan Pelaksanaan KKN untuk presentase tingkat Kecamatan. Format 6.

\subsubsection{Catatan dan Lembar Instruksi.}

Adalah buku yang berfungsi sebagai tempat DPL, Ketua Panitia, Tim Monitoring, meninggalkan catatan dan atau instruksi kepada peserta KKN. Buku ini tidak boleh diisi oleh selain DPL, Ketua Panitia, Rektor, Wakil Rektor, tim Monitoring. Format 7.

\subsubsection{Buku Tamu}

Setiap posko KKN wajib membuat buku tamu bagi tamu yang berkunjung ke Posko. Buku ini untuk melihat interaksi, respon dan empati warga kepada mahasiswa peserta KKN . Buku tamu bisa menggunakan buku album. Format 8 .

\subsubsection{Bukti Kegiatan}

Setiap kegiatan kerja kelompok harus memiliki bukti pelaksanaan, yakni daftar hadir rapat, dapat hadir pelatihan serta dapat ditambahkan dokumentasi kegiatan. Format 9.

\subsubsection{Laporan Kelompok Desa/Kelurahan}

Laporan Kelompok ini dibuat oleh setiap Desa/Kelurahan yang ditempati oleh peserta KKN. Laporan ini selanjutnya akan dipresentasekan ditingkat kecamatan diakhir pelaksanaan KKN. Laporan ini didasarkan kepada Rekapitulasi Catatan Aktifitas Mahasiswa KKN. Lampiran 1. 


\section{Format 1. Matriks Perencanaan dan Pelaksanaan Kegiatan KKN}

MATRIK RENCANA DAN PELAKSANAAN KEGIATAN

ANGKATAN XXVIII TAHUN 2019
Desa/Kelurahan .... Kecamatan ............ Kota/ Kab. ............... Propins

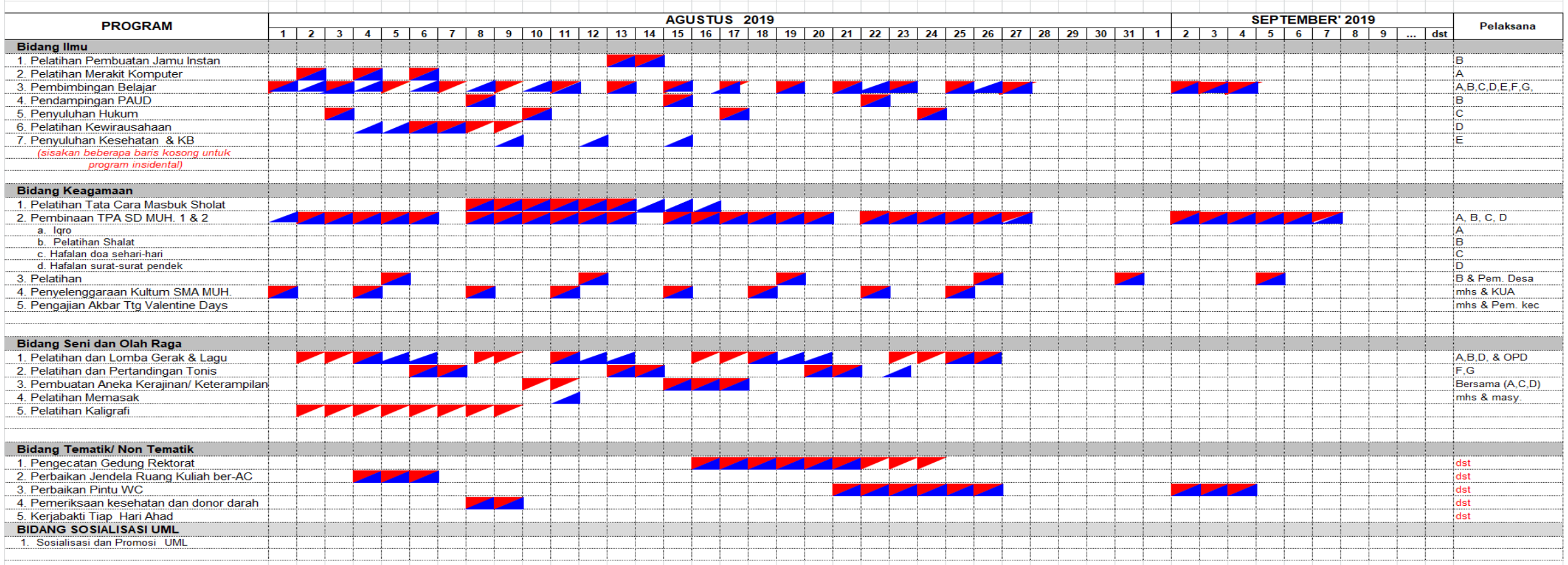

Keterangan

$\checkmark$ Pencana

Kepala Desa/Lurah

MPIIY

Ketua Kelompor

A: Amrullah
B: Bambang Ramadhan

B: Bambang Rama
C. Rizkia Arizona
D. Nanang Maruf

D. Nanang Mairu
E: Siti Sukemi

F. Zulta Nur Aini

H: Ramadhankiana
I: Prabawati Nurul Azm

(NPM: 17011007 / llmu Hukum

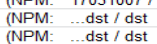

(NPM: ...dst/dst
(NPM: ...dst/dst
(NPM: dst /st

(NPM: ....dst/dst 
BUKU AKTIVITAS HARIAN MAHASISWA

KULIAH KERJA NYATA UNIVERSITAS MUHAMMADIYAH LUWUK

ANGKATAN XXVI TAHUN 2019

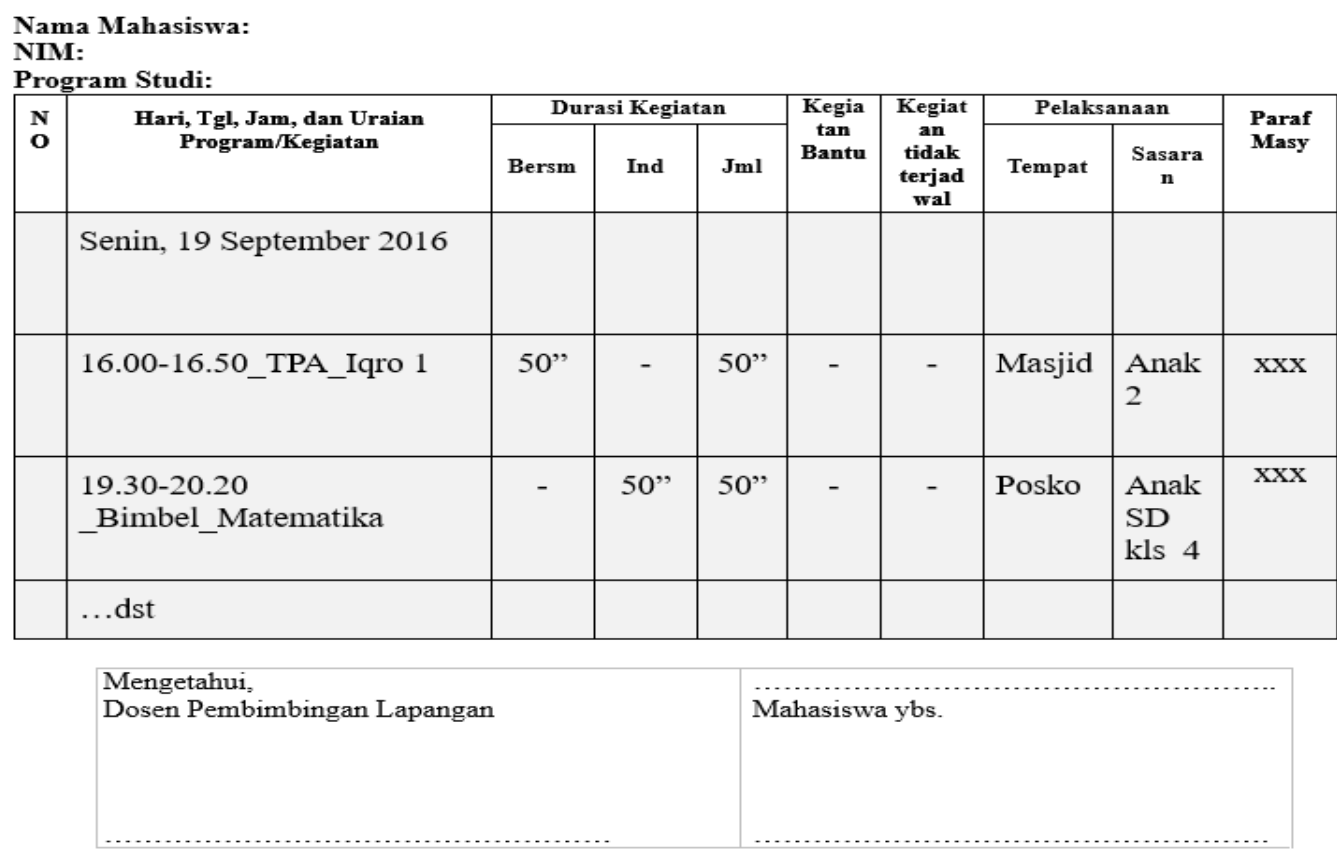

Format 3 dan Contoh Isian:

Format ini diisi dalam melakukan pendalaman hasil survey. Manfaat tahapan ini adalah untuk memperbaiki redaksi rencana kegiatan, merumuskan rencana kegiatan yang tidak/belum tertuang dalam hasil survey.

Nama dan NIM

GERAKAN SILATURRAHIM

Prodi, Fakultas

Desa/ Kelurahan

\begin{tabular}{|c|c|c|c|c|}
\hline \multirow[t]{2}{*}{ No. } & \multirow[t]{2}{*}{ Hari, Tanggal dan Waktu } & \multicolumn{2}{|c|}{ Orang yang Dikunjungi } & \multirow[t]{2}{*}{ Tanda Tangan } \\
\hline & & Nama & $\begin{array}{c}\text { Jabatan/ } \\
\text { Pekerjaan }\end{array}$ & \\
\hline 1. & Senin, 2 Feb 2019 & Amran & $\begin{array}{l}\text { Ketua Pemuda Al } \\
\text { Khairat }\end{array}$ & $\mathbf{X X X}$ \\
\hline 2. & Kamis, 5 Feb 2019 & Ibu Intan & $\begin{array}{l}\text { Ketua Wanita Al } \\
\text { Khairat }\end{array}$ & $\mathbf{x x X}$ \\
\hline 3. & & & & \\
\hline
\end{tabular}

Mengetahui,

Kordes/KorLur

Mahasiswa ybs 


\section{Format 4.}

\section{GERAKAN SHALAT JAMAAH}

Nama dan NIM

Prodi, Fakultas

Desa/ Kelurahan

\begin{tabular}{|c|c|c|c|c|c|c|}
\hline \multirow[t]{2}{*}{ No. } & \multirow{2}{*}{$\begin{array}{l}\text { Hari, Tanggal, dan } \\
\text { Nama Shalat }\end{array}$} & \multicolumn{4}{|c|}{ Jumlah Jamaah (beri tanda v) } & \multirow{2}{*}{$\begin{array}{l}\text { Imam/ } \\
\text { Ta'mir }\end{array}$} \\
\hline & & $\leq 9$ & $10-24$ & $25-49$ & $\geq 50$ & \\
\hline \multicolumn{7}{|l|}{1.} \\
\hline 1. & Subuh & & & & & \\
\hline 2. & Dzuhur & & & & & \\
\hline 3. & Ashar & & & & & \\
\hline 4. & Maghrib & & & & & \\
\hline 5. & Isya" & & & & & \\
\hline 6. & ...dst & & & & & \\
\hline & \multicolumn{3}{|l|}{$\begin{array}{l}\text { Mengetahui, } \\
\text { Kordes/Korlur }\end{array}$} & \multicolumn{3}{|c|}{$\begin{array}{l}\text { Mahasiswa ybs } \\
\text { Manan }\end{array}$} \\
\hline
\end{tabular}

\section{Format 5A :}

KARTU TUGAS DI LUAR LOKASI / IZIN MENINGGALKAN LOKASI TUGAS KKN

$\begin{array}{ll}\text { Nama } & : \\ \text { NPM } & : \\ \text { Prodi/ Fakultas } & : \\ \text { Desa/Kelurahan } & \text { : }\end{array}$

\begin{tabular}{|c|c|c|c|c|c|c|c|}
\hline No & \multicolumn{5}{|c|}{ Berangkat Meninggalkan lokasi } & \multicolumn{2}{|c|}{ Kembali } \\
\hline & $\mathrm{Hr}, \mathrm{tgl}, \mathrm{Pk}$ & Tujuan & Keperluan & waktu & Paraf & $\mathrm{Hr}, \mathrm{tgl}, \mathrm{Pk}$ & Paraf \\
\hline 1 & $\begin{array}{l}\text { Senin, 2, } \\
\text { III }\end{array}$ & Luwuk & $\begin{array}{l}\text { Menguhubungi } \\
\text { Pemateri } \\
\text { Pelatihan Kaligrafi }\end{array}$ & $\begin{array}{l}2 \times 1440 \\
\text { menit }\end{array}$ & $X X X^{*}$ & Rabu, 4,III & $X X X^{*}$ \\
\hline 2 & ..dst & & & & & & \\
\hline
\end{tabular}

* Paraf oleh Kordes/KorLur. 


\section{Format 5B}

\section{KARTU TUGAS DI LUAR LOKASI / IZIN MENINGGALKAN LOKASI NON TUGAS KKN}

\section{Nama}

NPM

Prodi/ Fakultas

Desa/Kelurahan

HP

\begin{tabular}{|l|l|l|l|l|l|l|l|}
\hline No & \multicolumn{4}{|c|}{ Berangkat Meninggalkan lokasi } & \multicolumn{2}{c|}{ Kembali } \\
\hline & $\mathrm{Hr}, \mathrm{tgl}, \mathrm{Pk}$ & Tujuan & Keperluan & waktu & Paraf & $\mathrm{Hr}$, tgl,Pk & Paraf \\
\hline 1 & $\begin{array}{l}\text { Senin, 2 } \\
\text { III }\end{array}$ & Luwuk & Mengambil uang & $\begin{array}{l}2 \times 1440 \\
\text { menit }\end{array}$ & $\mathrm{XXX}^{* *}$ & Rabu, 4,III & $\mathrm{XXX}^{* *}$ \\
\hline 2 & ..dst & & & & & & \\
\hline
\end{tabular}

${ }^{* *}$ Paraf oleh aparat atau sesuai arahan DPL. Format ini dibuat rangkap 2 satu ditinggalkan dan satu dibawa oleh peserta.

\section{Format 6. Rekapitulasi Aktifitas Harian Individu}

\section{REKAPITULASI AKTIVITAS MAHASISWA KULIAH KERJA NYATA}

Nama

NPM

Prodi dan Fakultas

Desa/ Kelurahan

A. Program dan Kegiatan

\begin{tabular}{|l|l|l|l|l|l|}
\hline \multirow{2}{*}{ No } & \multicolumn{1}{|c|}{ Bidang } & \multicolumn{2}{c|}{ Perencanaan } & \multicolumn{2}{c|}{ Pelaksanaan } \\
\cline { 3 - 6 } & & Kegiatan & JKEM & Kegiatan & JKEM $^{*}$ \\
\hline 1 & Keilmuan & & & & \\
\hline 2 & Keagamaan & & & & \\
\hline 3 & Seni dan Olahraga & & & & \\
\hline 4 & $\begin{array}{l}\text { Tematik dan Non } \\
\text { Tematik }\end{array}$ & & & & \\
\hline 5 & Sosialisasi kampus & & & & \\
\hline 6 & Pameran KKN & & & & \\
\hline 7 & Jumlah & & & \\
*am Kerja Efektif Mahasiswa.
\end{tabular}

B. Gerakan Sholat Berjama'ah

\begin{tabular}{|l|l|l|l|l|}
\hline No & Berjama'ah (menit) & Sholat Sendiri** & Halangan* $^{\star}$ & Total JKEM \\
\hline JKEM & & & & \\
\hline
\end{tabular}

** sedang tugas luar lokasi atau hal lainnya bagi perempuan.

"* khusus perempuan.

C. Kartu Tugas Diluar Lokasi

\begin{tabular}{|l|c|c|}
\hline No & $\begin{array}{c}\text { Meninggalkan Lokasi Karena tugas } \\
\text { (menit) }\end{array}$ & $\begin{array}{c}\text { Meninggalkan Lokasi Bukan Karena } \\
\text { tugas (menit) }\end{array}$ \\
\hline & & \\
\hline
\end{tabular}
2019

Kepala Desa/Lurah

Peserta KKN

Catatan : Semua Administrasi KKN diserahkan ke DPL 
Format 7. Lembar Catatan dan Instruksi

\begin{tabular}{|l|l|l|l|l|l|l|}
\hline No & Hari/tgl & Nama & Jabatan & Keperluan & $\begin{array}{c}\text { Isi Pesan/ } \\
\text { Instruksi }\end{array}$ & Tandatangan \\
\hline & & & & & & \\
\hline
\end{tabular}

Format 8. Buku Tamu

\begin{tabular}{|l|c|c|c|c|c|c|c|}
\hline No & $\begin{array}{c}\text { Hari/ } \\
\text { tanggal }\end{array}$ & Nama & Pekerjaan & Keperluan & Kesan & Pesan & $\begin{array}{c}\text { Tanda } \\
\text { tangan }\end{array}$ \\
\hline & & & & & & & \\
\hline
\end{tabular}

Format 9. Lembar bukti kegiatan:

Desa

Kecamatan

Nama Kegiatan

Form ini harus selalu disiapkan dan diisi oleh peserta kegiatan/ masyarakat setiap kegiatan kelompok maupun individu sebagai bukti pelaksanaan kegiatan

\begin{tabular}{|c|c|c|c|c|}
\hline No & Hari/Tanggal & Nama & Pekerjaan & Tanda tangan \\
\hline & & & & \\
& & & & \\
\hline
\end{tabular}




\section{ARTIKEL ILMIAH MAHASISWA}

Program artikel ilmiah pengabdian kepada masyarakat oleh mahasiswa adalah kegiatan menulis karya ilmiah. Sumber dan judul tulisan didasarkan pada kegiatan bidang ilmu yang ada dalam kertas Matriks Rencana dan Pelaksanaan Kegiatan. Setiap mahasiswa wajib membuat 1 buah artikel sesuai dengan program studi.

\section{Sistematika Artikel IImiah}

Artikel Ilmiah ditulis menggunakan huruf Times New Roman ukuran 12 dengan jarakbaris 1,15 spasi, ukuran kertas A-4, margin kiri $4 \mathrm{~cm}$, margin kanan, atas, dan bawah masing-masing $3 \mathrm{~cm}$, maksimal 8 halaman tidak termasuk sampul dan halaman pengesahan, dijilid sampul warna biru muda serta mengikuti sistematika sebagai berikut.

\section{HALAMAN SAMPUL (Lampiran 4.1)}

HALAMAN PENGESAHAN (Lampiran 4.2)

\section{ISI ARTIKEL :}

1. JUDUL

Judul tulisan hendaknya menggambarkan isi pokok tulisan secara ringkas dan jelas.

\section{NAMA PENULIS}

Nama-nama penulis dituliskan tepat dibawah judul, disertai dengan alamat institusi penulis, serta catatan kaki untuk penulis korespondensi.

3. ABSTRAK ditulis dalam Bahasa Indonesia. Abstrak berisi tidak lebih dari 250 kata dan merupakan intisari seluruh tulisan yang meliputi: latar belakang,tujuan, metode, hasil dan kesimpulan dan ditulis dengan jarak baris 1,0 spasi. Dibawah abstrak disertakan 3-5 kata-kata kunci (keywords).

\section{PENDAHULUAN}

Pendahuluan merupakan gambaran umum dari observasi awal dan fenomena mengenai topik yang diangkat. Latar belakang, rumusan, tujuan dari kegiatan pengabdian, atau yang lainnya serta manfaat untuk waktu yang akan datang ditunjukkan dalam pendahuluan. Dengan merujuk dari berbagai sumber pustaka, pandangan singkat dari para penulis lain yang pernah melakukan pembahasan topik terkait dapat dikemukakan di sini untuk menerangkan kemutakhiran substansi pekerjaan.

\section{TUJUAN}

Tujuan artikel ilmiah harus diungkapkan secara jelas dan mencerminkan judul artikel.

\section{METODE}

Metode berisi tentang waktu/lama kegiatan, dan tempat dilakukannya, bahan dan alat yang digunakan, prosedur kerja atau tahapan pelaksanaan. Metode harus dijelaskan secara lengkap agar orang lain dapat melakukan tahapan pengabdian untuk permasalahan yang sama.

\section{HASIL DAN PEMBAHASAN}

Bagian ini menjelaskan tentang apa saja yang diperoleh dari tahap observasi, pelaksanaan dan capaian kegiatan/hasil akhir. Pemaparan dapat dalam bentuk tabel dan gambar. Tidak ada spekulasi dan interpretasi dalam bagian ini, yang ada hanya fakta sesuai pelaksanaan kegiatan. Hasil dan Pembahasan handaknya menjadi satu kesatuan, dan tidak dipisah menjadi sub bab tersendiri. 


\section{KESIMPULAN}

Kesimpulan merupakan bagian akhir tulisan yang membawa pembaca keluar dari pembahasan. Secara umum kesimpulan menunjukkan jawaban atas tujuan yang telah dikemukakan dalam pendahuluan.

\section{DAFTAR PUSTAKA}

Daftar pustaka berisi informasi tentang sumber pustaka yang telah dirujuk dalam tubuh tulisan. Untuk setiap pustaka yang dirujuk dalam naskah harus muncul dalam daftar pustaka, begitu juga sebaliknya setiap pustaka yang muncul dalam daftar pustaka harus pernah dirujuk dalam tubuh tulisan. Format perujukan pustaka mengikuti Harvard style. Sistem Harvard menggunakan nama penulis dan tahun publikasi dengan urutan pemunculan berdasarkan nama penulis secara alfabetis. Publikasi dari penulis yang sama dan dalam tahun yang sama ditulis dengan cara menambahkan huruf $a, b$, atau $c$ dan seterusnya epat di belakang tahun publikasi (baik penulisan dalam daftar pustaka maupun sitasidalam naskah tulisan). Alamat Internet ditulis menggunakan huruf italic.

\section{Contoh :}

Buller H, Hoggart K. 1994a. New drugs for acute respiratory distress syndrome. NewEngland $\mathbf{J}$ Med 337(6): 435-439.

Grinspoon L, Bakalar JB. 1993. Marijuana: the Forbidden Medicine. London: Yale Univ Press. Palmer FR. 1986. Mood and Modality. Cambridge: Cambridge Univ Press. 


\section{BAB VI}

\section{EVALUASI DAN PENILAIAN KKN}

Kuliah Kerja Nyata secara akademik adalah mata kuliah wajib dalam struktur kurikulum. Evaluasi secara keseluruhan terhadap pelaksananaan Kuliah Kerja Nyata dilaksanakan oleh Tim Pembina, LP3M, DPL, Panitia Kuliah Kerja Nyata, dan masyarakat. Kegiatan evaluasi terdiri Evaluasi oleh Ketua Panitia, DPL dan Tim Monitoring.

Sedangkan penilaian akademik ditetapkan oleh Ketua LP3M sebagai Penanggungjawab matakuliah setelah melalui rapat penentuan nilai. Tim penentuan nilai akhir terdiri atas Pembina KKN, Ketua LP3M, bidang-bidang dalam LP3M, serta Ketua Panitia dan DPL sebagai anggota Tim Matakuliah. Penilaian KKN terbagi 2 tahapan yakni pembekalan dan kegiatan lapangan. Berikut adalah rincian lengkapnya:

\subsection{Pembekalan ( 1 sks)}

Nilai pembekalan adalah prasyarat mengikuti Kuliah Kerja Nyata. Nilai pembekalan dinyatakan dalam Jam Kerja Efektif Mahasiswa (JKEM) minimal 928 menit, merupakan penjumlahan dari komponen kehadiran pada pembekalan, dan nilai resume pembekalan.

Kehadiran : minimal 768 menit

Resume : minimal 8 buah setara waktu kerja 160 menit.

Penilaian dilakukan oleh Panitia KKN. Peserta yang dianggap gugur maka tidak diperkenankan mengikuti Kuliah Kerja Nyata dan menunggu KKN angkatan berikutnya.

\subsection{Penilaian Kegiatan Lapangan KKN-PPM (3 sks)}

\begin{tabular}{|c|l|l|r|}
\hline No & \multicolumn{1}{|c|}{ Indikator } & \multicolumn{1}{|c|}{ Poin Penilaian } & JKEM Minimal (menit) \\
\hline \multirow{2}{*}{1} & \multirow{2}{*}{ Sikap (A) } & Kehadiran & 12.960 \\
\cline { 3 - 4 } & & Bantu & 600 \\
\hline \multirow{2}{*}{2} & \multirow{2}{*}{ Administrasi (B) } & Kegiatan Terjadwal & 11.040 \\
\cline { 3 - 4 } & & Kegiatan tidak Terjadwal & 2000 \\
\hline \multirow{2}{*}{3} & \multirow{2}{*}{ Kinerja Kelompok (C) } & Sosialisasi & 480 \\
\cline { 3 - 4 } & & pameran & 960 \\
\hline 4 & Artikel (D) & Nilai laporan & 1.200 \\
\hline \multicolumn{2}{|l|}{ Total Poin } & & $\mathbf{2 9 . 2 4 0}$ \\
\hline
\end{tabular}

\section{Keterangan:}

1. JKEM terjadwal adalah kegiatan yang telah tercantum dalam kertas program kegiatan kerja.

2. JKEM tidak terjadwal adalah kegiatan yang muncul dalam rangka pelayanan atau membantu masyarakat/ tokoh masyarakat/ pemerintah desa, memakmurkan masjid, menghidupkan suasana Al Islam dIl, tetapi tidak tercantum dalam kertas matriks kegiatan kelompok.

3. Bantu adalah kegiatan membantu teman satu posko dalam kegiatan bidang ilmu.

4. Nilai JKEM kehadiran, JKEM terjadwal dan tidak terjadwal dihitung oleh DPL, sedangkan artikel oleh Tim Penilai LP3M.

\subsection{Nilai Akhir Peserta KKN-PPM}

Penilaian akhir ditetapkan Ketua LP3M melalui rapat penentuan nilai dengan memperhatikan dan mempertimbangkan jenis pelanggaran, hingga sanksi yang diterima peserta KKN. Penilaian akhir KKN merupakan penjumlahan dari ke-empat bagian penilaian: 


Nilai Akhir KKN $=$ Poin $A+$ Poin $B+$ Poin $C+$ poin $D$

$\begin{array}{ll}\text { Keterangan } & = \\ \text { Poin } \mathrm{A} & =\text { proporsi penilaian } 25 \% \\ \text { Poin } \mathrm{B} & =\text { proporsi penilaian } 30 \% \\ \text { Poin } \mathrm{C} & =\text { proporsi penilaian } 30 \% \\ \text { Poin } \mathrm{D} & =\text { proporsi penilaian } 15 \%\end{array}$

Sedangkan patokan acuan penilaian untuk nilai akhir KKN adalah:

\begin{tabular}{|c|c|c|c|}
\hline JKEM & Poin & Nilai & Bobot \\
\hline $29.240-32.351$ & $88-100$ & A & 4 \\
\hline $19.286-28.618$ & $72-87$ & B & 3 \\
\hline $9.954-13.687$ & $57-71$ & C & 2 \\
\hline $622-8.710$ & $42-56$ & D & 1 \\
\hline$<622$ & $<42$ & E & 0 \\
\hline
\end{tabular}

Jika dalam rapat penentuan nilai akhir terdapat komponen penilaian yang tidak lengkap hingga batas akhir, maka komponen tersebut bernilai nol dan nilai akhir tetap dikeluarkan dengan rekapitulasi normal.

\subsection{Nilai Tunda (nilai T)}

Nilai tunda diberikan kepada peserta disebabkan karena:

1. Masih memiliki tunggakan keuangan yang berhubungan dengan $\mathrm{KKN}$.

2. Administrasi kepesertaan $\mathrm{KKN}$ ada yang belum lengkap.

3. Pelanggaran pasca kegiatan lapangan (sanksi poin C).

Tenggat atau batas akhir nilai tunda diputuskan dalam rapat penetapan nilai. Jika hingga batas waktu tidak ada penyelesaian, maka nilai dikeluarkan sesuai apa adanya. 


\section{Lampiran 1. Laporan Kelompok}

\subsection{Sistematika Laporan Kelompok Untuk Seminar}

HALAMAN JUDUL

HALAMAN PENGESAHAN

KATA PENGANTAR

DAFTAR ISI

DAFTAR TABEL

DAFTAR LAMPIRAN

\section{BAB I KEADAAN UMUM LOKASI}

1.1. Berisi letak geografis meliputi nama dan batas wilayah, peta, aksebilitas.

1.2. Keadaan geografi meliputi suku dan budaya, jumlah penduduk, tingkat pendidikan, sumber matapencaharian, sarana dan prasarana pendidikan, ibadah, serta perekonomian.

1.3. Potensi Sumber Daya Alam.

1.4. Aktifitas Keagamaan dan budaya.

BABII PROGRAM DAN KEGIATAN KERJA

Tuliskan nama Program dan Kegiatan, jelaskan rencana waktu kerja, serta jelaskan hasil akhir yang diinginkan.

\section{BAB III PELAKSANAAN KEGIATAN KERJA}

Jelaskan jalannya pelaksanaan kegiatan dan capaian yang diperoleh dari hasil akhir yang diinginkan.

\section{BABIV REKOMENDASI}

Berisi saran atau solusi atau pemecahan masalah yang diberikan sebagai tindak lanjut dari pelaksanaan kegiatan kerja. Rekomendasi ini berasal dari mahasiswa kepada stageholder atau pemerintah baik desa maupun kecamatan sebagai buah pemikiran akademisi.

\section{LAMPIRAN}

Rekapan Aktifitas Mahasiswa KKN Desa/Kelurahan ditambah rekaan pembiayaan (Lampiran 1.4).

Dokumentasi kegiatan Kuliah Kerja Nyata

\section{Catatan:}

1. Laporan ditulis menggunakan kertas ukuran A4, ditulis menggunakan spasi 1,5 dengan Font Times New Roman 12,

2. laporan digandakan dan dijilid saat pelaksanaan seminar dengan sampul warna hijau;

3. Diperbaiki setelah pelaksanaan seminar

4. Setelah ditandasyahkan kembali oleh DPL disetorkan kepada LP3M dalam bentuk CD dengan format pdf. 


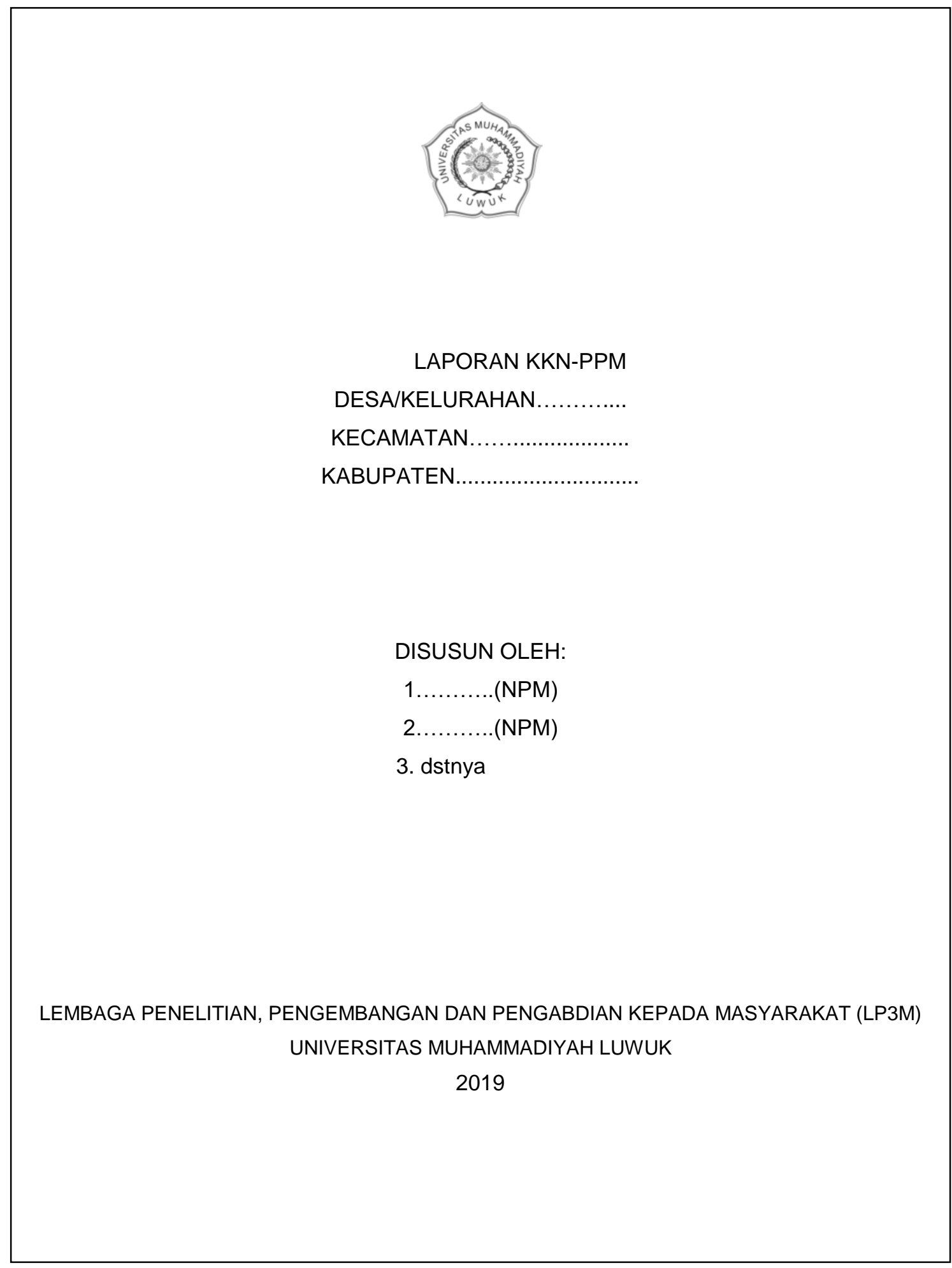


1.3. Halaman Pengesahan Laporan

\section{HALAMAN PENGESAHAN}

Desa (Kelurahan)

Kecamatan

Kabupaten

Nama nama peserta

:1........ (NPM)

2......dst

$.20 \ldots$

Mengetahui

Menyetuji

Kepala Desa (Lurah)

Dosen Pembimbing Lapangan

NIDN. 
1.4. Matriks Program dan Kegiatan Kerja untuk Lampiran Laporan Kelompok

KELOMPOK BIDANG KEILMUAN/BIMBINGAN BELAJAR

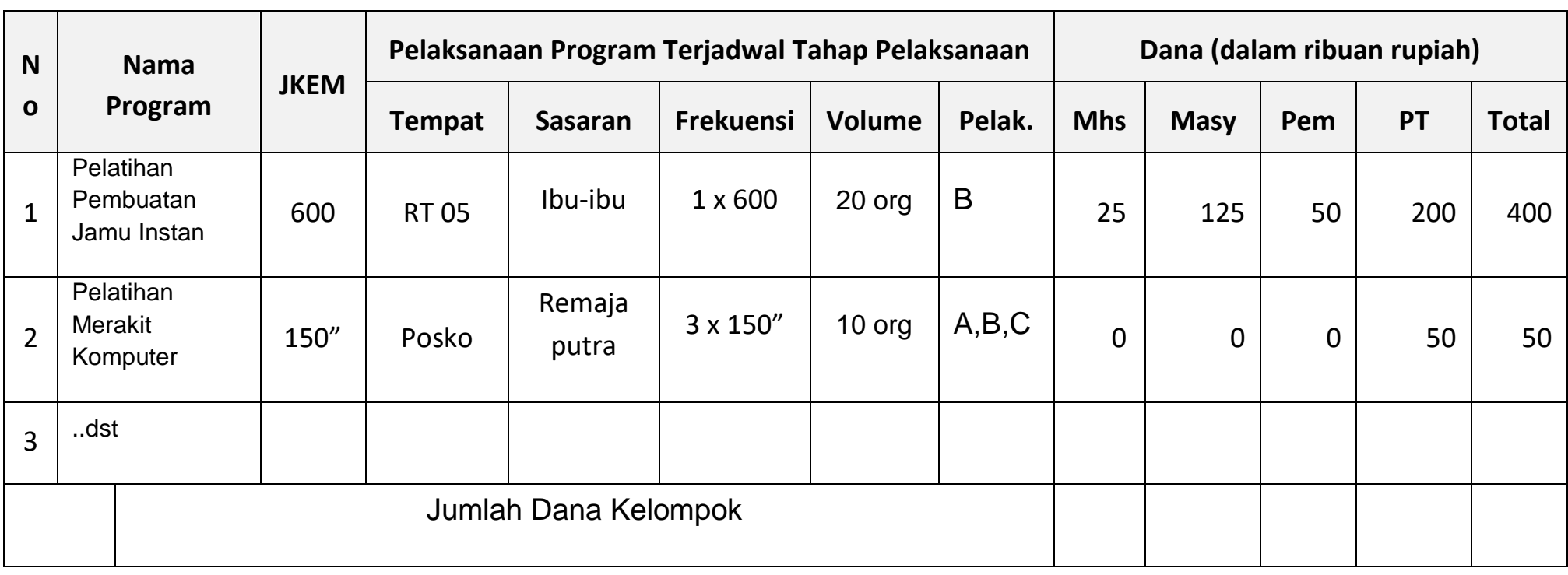

Demikian seterusnya untuk bidang lainnya.
II. KELOMPOK BIDANG KEAGAMAAN
III. KELOMPOK BIDANG SENI DAN OLAHRAGA
IV. KELOMPOK TEMATIK DAN NON TEMATIK
V. KEGIATAN WAJIB UNIVERSITAS. 


\section{Lampiran 2. Artikel Ilmiah Mahasiswa}

\subsection{Halaman Sampul Artikel IImiah Mahasiswa}

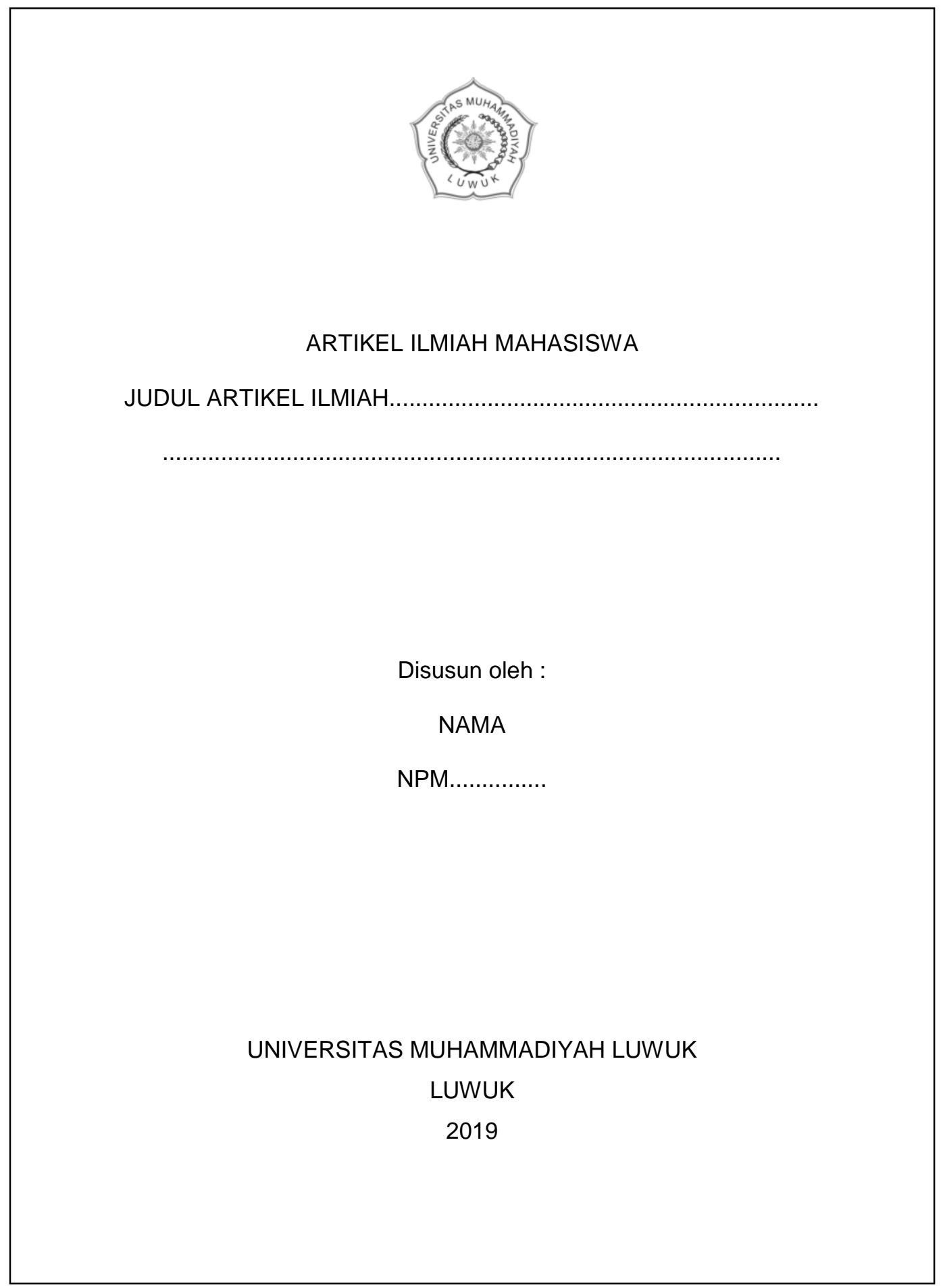




\subsection{Halaman Pengesahan}

HALAMAN PENGESAHAN

Judul Artikel IImiah:

Bidang kegiatan : Artikel Ilmiah Mahasiswa

Nama

NIM

Program Studi

Fakultas

Universitas : $\quad$ Muhammadiyah Luwuk

Luwuk, .2018

Mengetahui

Ketua LP3M

Dosen Pembimbing Lapangan

$($............................)

NIDN.

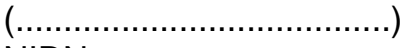

NIDN. 


\title{
PENDAMPINGAN BUDIDAYA IKAN LELE DUMBO DALAM KOLAM TERPAL
}

\author{
Sri Sukari Agustina \\ Fakultas Perikanan Universitas Muhammadiyah Luwuk \\ Email : asrisukari@yahoo.com
}

\begin{abstract}
ABSTRAK
Tujuan utama pelaksanaan kegiatan ini adalah untuk meningkatkan partisipasi masyarakat Desa Buon Mandiri Kecamatan Luwuk Utara Kabupaten Banggai dalam mengelola potensi lahan yang tersedia untuk peningkatan produksi budidaya ikan lele dumbo dengan media kolam terpal dan perluasan lapangan kerja. Metode pelaksanaan yang dilakukan untuk mewujudkan luaran kegiatan ini yaitu metode partispatif, dimana seluruh kegiatan dilaksanakan bersama masyarakat. Adapun pelaksanaan kegiatan meliputi sosialisasi mengenai manfaat budidaya ikan lele dumbo dengan media kolam terpal, pemaparan materi dilanjutkan dengan pelatihan teknis yang dilaksanakan secara langsung di lapangan bersama masyarakat menyangkut teknik budidaya ikan lele dumbo dengan media kolam terpal. Output kegiatan ini, selain kesadaran warga masyarakat memanfaatkan potensi lahan yang tersedia, juga terdapatnya sentra budidaya ikan lele dumbo dengan media kolam terpal di Desa Buon Mandiri sehingga usaha budidaya ikan lele dumbo yang dilakukan mampu meningkatkan kesejahteraan masyarakat dan memperluas lapangan kerja.
\end{abstract}

Kata kunci : lele dumbo, kolam terpal, peningkatan produkti, lapangan kerja

\section{PENDAHULUAN}

Ikan lele dumbo termasuk ikan yang paling mudah diterima masyarakat karena memiliki banyak kelebihan, di antaranya pertumbuhannya yang cepat' memiliki adaptasai terhadap lingkungan yang tinggi seperti dapat ditebar dengan kepadatan tinggi per satuan luas kolam dan bisa hidup di air dengan kadar oksigen yang rendah, rasanya enak dan kandungan gizinya tinggi. Ikan lele dumbo memiliki tingkat konversi pakan menjadi bobot tubuh yang baik, sehingga memiliki pertumbuhan cepat.

Budi daya ikan lele dumbo umumnya dilakukan di kolam-kolam galian konvesional, namun kendala yang sering dihadapi oleh pembudidaya adalah ketika kolam ikan dilanda banjir. Dengan pembuatan kolam dari terpal kemungkinan tersebut bisa dihindari, karena kolam terpal ini bisa dibuat dengan posisi berada di atas tanah dengan dinding dari kayu kemudian dilapis terpal. Kolam terpal bisa dibuat di medan yang tidak memungkinkan untuk membudidayakan ikan, misalnya tanah dengan medan poros, tanah pasir, ruang sempit, dan lain-lain. Keunggulan budidaya ikan lele dumbo dalam kolam terpal yaitu praktis dan mudah, investasi kecil, tidak mudah terkena banjir, kontaminasi dengan tanah yang tidak diketahui kualitasnya dapat dihindari, kontrol terhadap kualitas dan kuantitas air lebih mudah, mudah melakukan pengeringan dan pembersihan, mudah melakukan panen dan bisa dipindahkan

Besarnya potensi budidaya ikan lele dumbo dalam kolam terpal tersebut maka dipandang perlu untuk melakukan usaha budidaya di Desa Buon Mandiri yang merupakan salah satu desa di wilayah Kecamatan Luwuk Utara yang berjarak $17 \mathrm{Km}$ ke arah timur dari ibu kota Kecamatan, 630 Km dari ibu kota Propinsi Sulawesi Tengah. Desa Buon Mandiri memiliki luas wilayah seluas \pm 3.333 $\mathrm{km}^{2}$ secara administratif terdiri dari 2 Dusun. Wilayah Desa Buon Mandiri mempunyai ketinggian meter dari permukaan laut dengan bentuk permukaan tanah dataran (30\%), perbukitan (30\%) dan 
pegunungan (40.\%). Mengingat efisiensi dan intensifikasi lahan maka budidaya ikan lele dumbo dalam kolam terpal sangatlah tepat untuk diterapkan di wilayah Desa Buon Mandiri Kecamatan Luwuk Utara Kabupaten Banggai, karena lingkungan Desa Buon Mandiri memiliki potensi untuk mengembangkan budidaya ikan lele dumbo sebagai mata pencaharian alternatif dalam meningkatkan kesejahteraan dan tingkat pendapatan masyarakat serta memperluas lapangan kerja.

\section{TUJUAN}

Tujuan kegiatan ini adalah untuk meningkatkan pengetahuan dan keterampilan masyarakat dalam budidaya ikan lele dumbo di kolam terpal yang.secara umum mencakup peningkatan produksi, peningkatan partisipasi masyarakat dan perluasan lapangan kerja

\section{METODE}

\section{Waktu dan Tempat Pelaksanaan Kegiatan}

Kegiatan ini dilaksanakan pada bulan September 2015 sampai dengan bulan Februari 2016, bertempat di Dusun I dan Dusun II Desa Buon Mandiri Kecamatan Luwuk Utara Kabupaten Banggai.

\section{Alat dan Bahan}

Alat-alat yang dipergunakan dalam kegiatan ini yaitu gergaji, palu, paku 5 dan $7 \mathrm{~cm}$, serok, baskom, ember dan timbangan pakan. Sedangkan bahan yang digunakan yaitu benih ikan lele dumbo, pakan pelet, papan, latah ukuran 4 X6, terpal ukuran 3 X $4 \mathrm{~m}^{2}$, kotoran sapi.

\section{Prosedur Kerja}

Pada tahap pelaksanaan kegiatan dimulai dengan sosialisasi kepada masyarakat sasaran di Desa Buon Mandiri Kecamatan Luwuk Utara Kabupaten Banggai, dilanjutkan dengan pelaksanaan kegiatan-kegiatan pelatihan. Tahapan-tahapan dengan metode pelaksanaan kegiatan disajikan pada Tabel berikut.

Tabel : Metode pelaksanaan kegiatan

\begin{tabular}{|c|c|c|c|}
\hline $\begin{array}{c}\text { Tahapan } \\
\text { Pelaksanaan }\end{array}$ & Kegiatan & Metode & Materi \\
\hline Pelaksanaan & $\begin{array}{l}\text { Sosialisasi ke } \\
\text { masyarakat } \\
\text { sasaran }\end{array}$ & $\begin{array}{l}\text { Pertemuan } \\
\text { dengan } \\
\text { masyarakat }\end{array}$ & $\begin{array}{l}\text { - Mekanisme pelaksanaan } \\
\text { kegiatan } \\
\text { - Program-program yang akan } \\
\text { dilaksanakan }\end{array}$ \\
\hline & $\begin{array}{l}\text { Pelaksanaan } \\
\text { pelatihan teknis }\end{array}$ & Partisipatif & $\begin{array}{l}\text { - Pelatihan pembuatan kolam } \\
\text { terpal } \\
\text { - Pelatihan budidaya ikan lele } \\
\text { dumbo dengan media kolam } \\
\text { terpal } \\
\text { - Pelatihan penumbuhan pakan } \\
\text { alami } \\
\text { - Pelatihan tata cara penebaran } \\
\text { benih ikan } \\
\text { - Pelatihan penanganan pasca } \\
\text { panen ikan }\end{array}$ \\
\hline
\end{tabular}




\section{HASIL DAN PEMBAHASAN}

Pelaksanaan kegiatan "Budidaya ikan lele dumbo dengan media kolam terpal di Desa Buon Mandiri Kecamatan Luwuk Utara Kabupaten Banggai" pada kelompok pembudidaya lele dumbo di Desa Buon Mandiri Kecamatan Luwuk Utara sampai pada bulan Februari 2016 telah dilaksanakan $100 \%$ program yaitu: sosialisasi mengenai manfaat budidaya ikan lele dumbo dengan media kolam terpal, pelatihan teknik pembuatan kolam terpal dan penumbuhan pakan alami, pelatihan tata cara penebaran benih ikan lele dumbo dan penanganan pasca panen ikan lele dumbo.

Pada tahap awal pelaksanaan program dilaksanakan kegiatan berupa sosialisasi dan kegiatan pelatihan, persiapan tutor, persiapan peralatan, dan koordinasi dengan peserta kegiatan. Sosialisasi dan kegiatan pelatihan dilaksanakan bersama tim pengusul didasari oleh analisis situasi yang dibuat berdasarkan permasalahan yang dihadapi oleh kelompok pembudidaya ikan lele dumbo. Perancangan ini dilaksanakan pada bulan September 2015 yang juga melibatkan peran serta aktif peserta program pengabdian kepada masyarakat untuk membuat skala prioritas program yang dilaksanakan. Perencanaan ini berjalan dengan sangat baik berkat peranan aktif tim pelaksana dan peserta yang menjadi mitra program.

Persiapan tutor dan instruktur dilaksanakan pada awal kegiatan untuk mematangkan kembali program - program yang akan dilaksanakan kepada mitra, sehingga terjadi sinergi yang baik dalam kegiatan ini. Persiapan tutor dan instruktur ini meliputi: mencetak materi pelatihan dan buku panduan untuk pembudidaya ikan lele dumbo di Dusun 1 dan Dusun 2 sesuai sasaran yang dituju. Persiapan yang dilaksanakan berikutnya berupa persiapan peralatan dan bahan yang dilaksanakan dengan menyiapkan perangkat LCD dan laptop/komputer sebagai media pendukung realisasi kegiatan, dan bahan pelatihan budidaya ikan lele dalam kolam terpal.

Dalam rangka penyamaan persepsi dan waktu pelaksanaan kegiatan pada kelompok budidaya ikan lele dumbo, maka dilaksanakan kegiatan sosialisasi dan koordinasi dengan peserta. Hal ini dilaksanakan untuk mendapatkan kesepakatan waktu dalam pelaksanaan program, sangat disyukuri peserta kegiatan sangat antusias dalam menerima sosialisasi program sehingga tidak ada halangan yang berarti dalam pelaksanaan kegiatan ini.

\section{A. Sosialisasi mengenai manfaat budidaya ikan lele dumbo dengan media kolam terpal}

Kegiatan ini dilaksanakan pada bulan Juli 2015, bertempat di Balai Desa Buon Mandiri Kecamatan Luwuk Utara Kabupaten Banggai. Peserta kegiatan adalah masyarakat Desa Buon Mandiri. Tujuan daripada kegiatan ini adalah meningkatnya pengetahuan dan keterampilan masyarakat dalam budidaya ikan lele dumbo dengan media kolam terpal dan meningkatnya produktivitas usaha di Desa Buon Mandiri. Dalam pelaksanaan sosialisasi ini tidak ditemukan kendala yang berarti karena respon yang sangat bagus dari setiap kelompok pembudidaya lele dumbo dalam mengikuti pelaksanaan kegiatan ini.

Kegiatan sosialisasi mengenai manfaat budidaya ikan lele dumbo dengan media kolam terpal ini diharapkan kedepannya terbentuk kelompok budidaya ikan lele dumbo dengan media kolam terpal dan terdapatnya sentra budidaya ikan lele dumbo dengan media kolam terpal di wilayah Desa Buon

Mandiri Kecamatan Luwuk Utara Kabupaten Banggai. Gambar kegiatan sosialisasi mengenai manfaat budidaya ikan lele dumbo dengan media kolam terpal tersaji pada Gambar 1. 


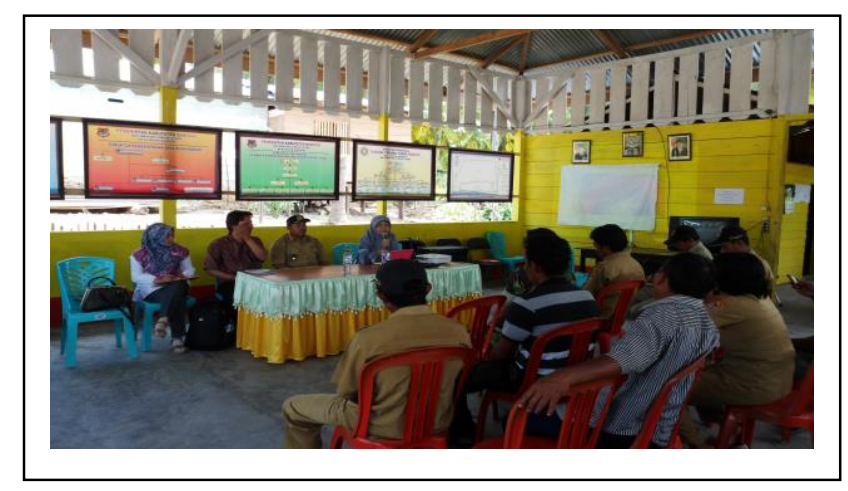

Gambar 1. Sosialisasi mengenai manfaat budidaya ikan lele dumbo dengan media kolam terpal

\section{B. Pelatihan teknik pembuatan kolam terpal dan penumbuhan pakan alami}

Pelatihan teknik pembuatan kolam terpal dan penumbuhan pakan alami pada pembudidaya lele dumbo (Kelompok Lele 1 dan Kelompok Lele 2) di Desa Buon Mandiri Kecamatan Luwuk Utara Kabupaten Banggai dilaksanakan pada tanggal 15 September 2015 di halaman Balai Desa (Dusun 1). Pelatihan ini bertujuan untuk meningkatnya pengetahuan dan keterampilan masyarakat pembudidaya lele dumbo yang sudah terbentuk tentang teknik pembuatan kolam terpal dan penumbuhan pakan alami dalam budidaya ikan lele dumbo dengan media kolam terpal. Gambar kegiatan pelatihan teknik pembuatan kolam terpal dan penumbuhan pakan alami disajikan pada Gambar 2 dan Gambar 3.
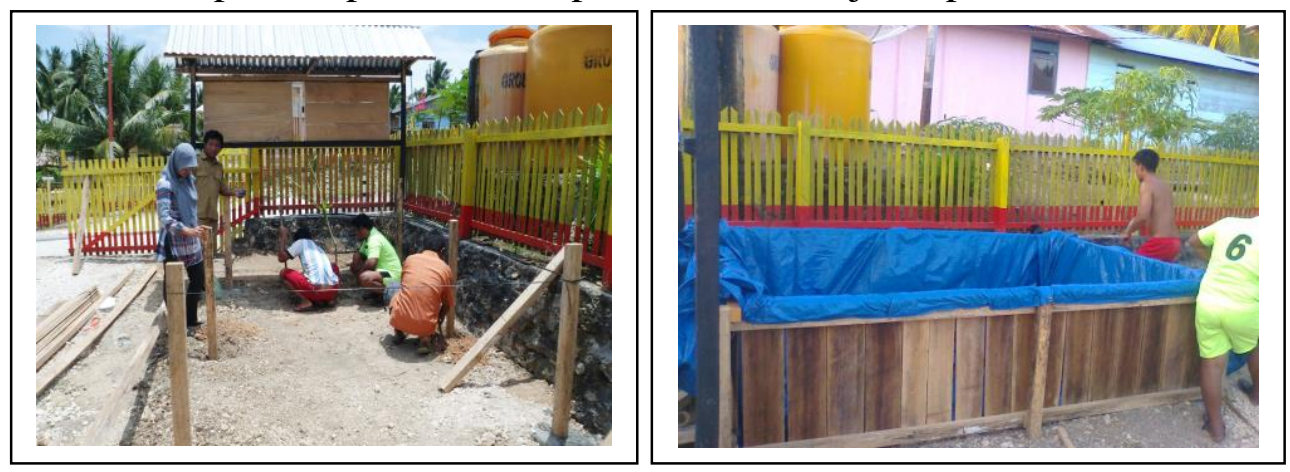

Gambar 2. Teknik pembuatan kolam terpal
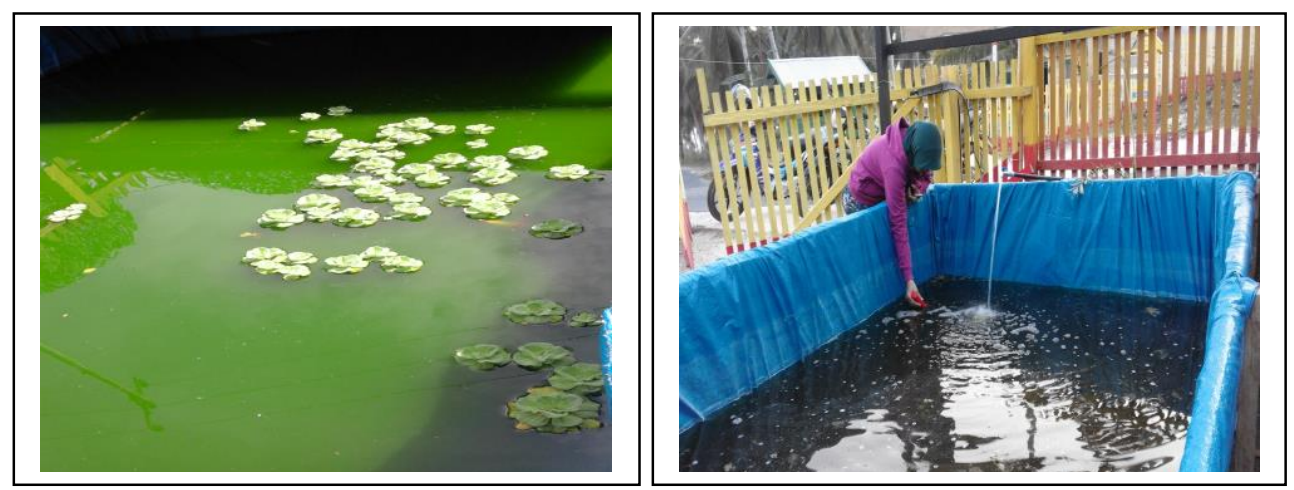

Gambar 3. Teknik penumbuhan pakan alami

Kegiatan pelatihan teknik pembuatan kolam terpal dan penumbuhan pakan alami terdiri dari pemaparan materi kegiatan dan kegiatan teknis di lapangan. Peserta kegiatan adalah masyarakat Desa Buon Mandiri yang terdiri dari 2 kelompok pembudidaya ikan lele dumbo (Kelompok Lele 1 dan Kelompok Lele 2). Dalam pelaksanaan kegiatan ini berhasil 100\% dan tidak ditemukan kendala yang 
berarti. Ketersediaan peralatan dan bahan untuk pembuatan kolam terpal dan penumbuhan pakan alami sangat mendukung dalam kegiatan ini. Respon dari setiap kelompok pembudidaya lele dumbo dalam mengikuti pelaksanaan kegiatan ini sangat mendukung. Kegiatan ini diharapkan agar masyarakat Desa Buon Mandiri dapat memanfaatkan secara optimal lahan kolam yang tersedia di desa untuk budidaya ikan lele dumbo.

\subsection{Pelatihan tata cara penebaran benih ikan lele dumbo dan penanganan pasca panen}

Pelatihan tata cara penebaran benih ikan lele dumbo, dan penanganan pasca panen lele dumbo di Desa Buon Mandiri Kecamatan Luwuk Utara Kabupaten Banggai dilaksanakan pada tanggal 28 November 2015 di halaman Balai Desa (Dusun 1). Pelatihan ini bertujuan untuk meningkatnya pengetahuan dan keterampilan masyarakat pembudidaya lele dumbo dalam tata cara penebaran benih ikan lele dumbo serta penanganan pasca panen. Kegiatan pelatihan ini terdiri dari pemaparan materi kegiatan dan kegiatan teknis di lapangan. Peserta kegiatan adalah masyarakat Desa Buon Mandiri yang terdiri dari 2 kelompok pembudidaya ikan lele dumbo (Kelompok Lele 1 dan Kelompok Lele 2). Dalam pelaksanaan kegiatan ini berhasil $100 \%$ dan tidak ditemukan kendala yang berarti. Ketersediaan peralatan dan bahan untuk tata cara penebaran benih ikan lele dumbo, dan penanganan pasca panen lele dumbo sangat mendukung dalam kegiatan ini.

Pelaksanaan kegiatan pelatihan berjalan dengan lancar dan baik terlihat dari besarnya perhatian dari anggota kelompok dalam menyimak serta memperhatikan materi-materi yang disampaikan juga pelaksanaan secara teknis di lapangan. Kegiatan ini diharapkan masyarakat mengetahui tata cara penebaran benih ikan lele dumbo dan penanganan pasca panen serta usaha budidaya ikan lele yang dilakukan mampu meningkatkan kesejahteraan masyarakat dan memperluas lapangan kerja. Gambar kegiatan pelatihan tata cara penebaran benih ikan lele dumbo, dan penanganan pasca panen disajikan pada Gambar 4.
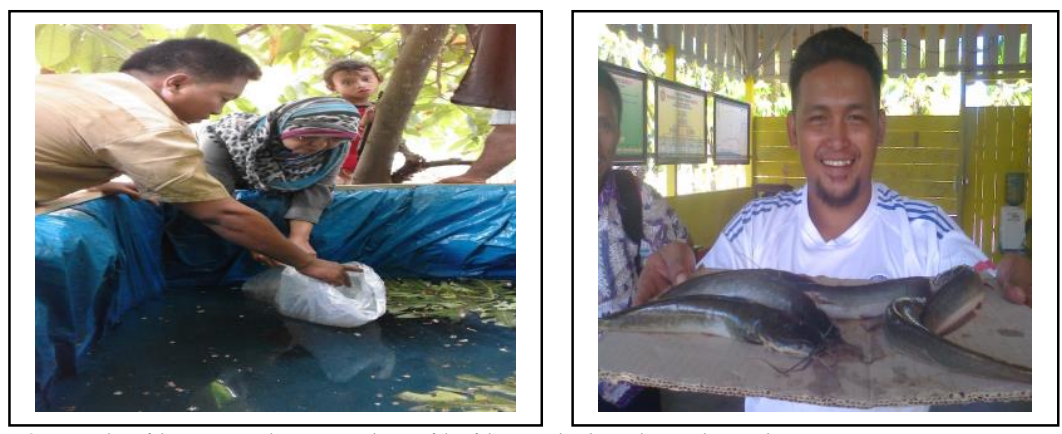

Gambar 4. Teknik penebaran benih ikan lele dumbo dan penanganan pasca panen

\section{KESIMPULAN}

Kesimpulan yang dapat diperoleh dari pelaksanaan program pengabdian kepada masyarakat pengembangan desa binaan "budidaya ikan lele dumbo dengan media kolam terpal di Desa Buon Mandiri Kecamatan Luwuk Utara Kabupaten Banggai” pada kelompok pembudidaya ikan lele dumbo adalah:

1. Tingkat partisipasi yang tinggi dari mitra program pengabdian kepada masyarakat memberikan dampak positif bagi pelaksanaan program, terlihat dari sosialisasi dan pelatihan yang diberikan dapat berjalan dengan baik

2. Pelaksanaan program mampu menghasilkan luaran-luaran yang diharapkan oleh program pengabdian kepada masyarakat ini, termasuk dalam hal peningkatan kesejahteraan masyarakat Desa Buon Mandiri. 


\section{DAFTAR PUSTAKA}

Darseno. 2010. Buku Pintar Budidaya dan Bisnis Lele. Agromedia Pustaka. Jakarta.

Khairuman, Sihombing T. dan Amri K. 2008. Budidaya Lele Dumbo Di Kolam Terpal. Agromedia Pustaka. Jakarta.

Rencana Pembangunan Jangka Menengah (RPJM) Desa Buon Mandiri 2015.

Widodo, M.S. dan Fakhri M. 2012. IbM Kelompok Pembudidaya Ikan Lele Dumbo Di Kabupaten Probolinggo. Lembaga Penelitian dan Pengabdian kepada Masyarakat Universitas Brawijaya Malang. 